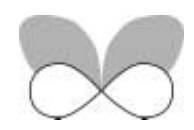

\title{
Availability of food resources, distribution of invasive species, and conservation of a Hawaiian bird along a gradient of elevation
}

Paul C. Banko*, Peter T. Oboyski ${ }^{1}$, John W. Slotterback, Steven J. Dougill, Daniel M. Goltz, Luanne Johnson ${ }^{2}$, Megan E. Laut ${ }^{3}$ and T. Colleen Murray US Geological Survey, Pacific Island Ecosystems Research Center, Kïlanea Field Station, Hawai'i National Park, HI, USA

\begin{abstract}
Aim We evaluated how an elevation gradient affects: (1) the availability of food required by a specialist seed-eater, Loxioides bailleui Oustalet (Drepanidinae), or palila, and hence the distribution of this endangered Hawaiian bird, and (2) the distribution of alien threats to Loxioides populations, their primary foods, and their dry-forest habitat, and hence strategies for their conservation.
\end{abstract}

Location We worked throughout the subalpine forest that encircles Mauna Kea Volcano, Hawai' $i$ Island, but we focused our studies mainly on the western slope between 2000 and $3000 \mathrm{~m}$ elevation, where the gradient of elevation was greatest and palila were most abundant.

Methods We determined phenology and productivity patterns of the endemic dry-forest tree species, Sophora chrysophylla (Salisb.) Seem. (Fabaceae), or māmane, which provides Loxioides with most of their food, and another common endemic tree, Myoporum sandwicense A. Gray (Myoporaceae), or naio, which provides some resources, along a 786-m elevation gradient at monthly intervals for 10 years (Sophora only). We also determined the availability each month of moth larvae (Lepidoptera) for that were important in the diet of nestling and adult palila. In addition, we documented the incidence of parasitism on moth larvae by several wasp (Hymenoptera) and fly (Diptera) species, and we determined the distribution of predatory wasps and ants (Hymenoptera), which potentially threaten insect prey of birds. Percentage cover of alien grass species that pose fire threats in palila habitat and other weeds were assessed during one survey. Small mammal abundance and distribution were determined by trapping during three (rodent) or five (carnivore) surveys.

Results Sophora flower and seed (pod) availability varied predictably along the elevation gradient, with about 4 months separating peaks in reproduction at high and low elevations. This, together with highly variable production of flowers and pods within elevation strata, resulted in Sophora resources being available to Loxioides throughout the year on the western slope of Mauna Kea. Sophora produced flowers and pods more seasonally where gradients of elevation were short; thus, resources were available less consistently. In contrast, Myoporum produced flowers and fruits with little variation with respect to season or elevation. The availability of important insect prey of Loxioides was also related to elevation, in part because threats to Lepidoptera larvae from parasitic wasps were generally less at higher elevations. Threats to insect prey from predatory ants was also less at higher elevations but the abundance of predatory wasps was not related to elevation. Several weeds that pose the most serious threats to Loxioides habitat were more abundant at mid and low elevations, and alien grass cover was somewhat greater at mid elevation, thereby increasing fire risks in the

\footnotetext{
*Correspondence: USGS-Pacific Island Ecosystems Research Center, Kīlauea Field Station, PO Box 44, Hawai‘i National Park, HI 96718, USA.

E-mail: paul_banko@usgs.gov

${ }^{1}$ Present address: ESPM, Insect Biology, 201 Wellman Hall - MC3112, University of California, Berkeley, CA 94708-3112, USA.

${ }^{2}$ Present address: 12528, Odell Road NE, Duvall, WA 98019, USA.

${ }^{3}$ Present address: Hawai'i Natural Heritage Program, University of Hawai'i at Mānoa, Center for Conservation Research and Training, 3050 Maile Way, Gilmore 409, Honolulu, HI 96822, USA.
} 
centre of Loxioides habitat. Predatory mammals, in particular Felis catus Linnaeus, were common throughout the subalpine forest of Mauna Kea. However, Rattus rattus Linnaeus was rare, especially at higher elevations, whereas Mus musculus Linnaeus was more abundant at lower elevations.

Main conclusions Loxioides are concentrated in habitat that is distributed along a substantial gradient of elevation at least in part because food is available throughout the year and threats to food resources are less concentrated. To recover Loxioides elsewhere in its former range, habitats must be restored and alien threats reduced along extensive elevation gradients. Conservation along environmental gradients will likely benefit other Hawaiian birds that track the availability of food across landscapes or that have been stranded in the higher portions of their original ranges because of the greater impacts of alien diseases, predators, food competitors, and habitat stressors at lower elevations.

\section{Keywords}

Elevation gradient, food availability, alien species, tree phenology, insect parasitism, subalpine dry forest, Hawaiian bird conservation, Loxioides bailleui, Sophora chrysophylla, island ecology.

\section{INTRODUCTION}

Environmental gradients create variation in habitat that is predictable over time and space, thus promoting biodiversity. Gradients of elevation, precipitation, and other environmental factors also increase species persistence because individuals are able to exploit resources in a variety of ways along a continuum. Bird species with specialized diets may be constrained by food availability on islands because they are often restricted to relatively small, homogeneous habitat patches. In the Hawaiian Archipelago, most bird species are found on only one or two islands and are further restricted with regard to habitat type. For example, many species are distributed only in dry or wet forests. Hawaiian honeycreepers (Drepanidinae) are among the best examples of adaptive radiation, and their dazzling array of bill forms illustrates their high degree of specialization on fruit, seed, nectar, and invertebrate foods (Freed et al., 1987). All of the most highly specialized honeycreepers vanished or became rare and localized (and now considered endangered), indicating that food resources became limited over large portions of their ranges.

Gradients of elevation and other environmental factors provide insights into patterns of avian community structure, richness, diversity, distribution, density, phenology, and habitat use (Terborgh, 1977; Sabo, 1980; Karr \& Freemark, 1983; Finch, 1991; Rahbek, 1995, 1997; Remsen \& Graves, 1995; Young et al., 1998; Martin, 2001). Although food availability does not always explain patterns of habitat use by birds along elevation gradients (Repasky \& Schluter, 1994), several studies demonstrate that species and guilds of birds, especially tropical frugivores, track food resources along gradients of elevation, rainfall, or habitat type (Wheelwright, 1983; Loiselle \& Blake, 1991; Poulin et al., 1992). In continental environments, however, there are few opportunities to evaluate the influence of environmental gradients on food availability in simple habitats. Neither have continental studies considered how native species and their habitats are threatened by alien species along environmental gradients. Our purpose is to examine patterns of food availability and alien threats as they affect the ecology and conservation of a highly specialized seed-eater, Loxioides bailleui Oustalet (palila), and its dry forest habitat along a 786-m gradient of elevation on Mauna Kea, Hawai'i. Loxioides are the last seed-eating members of the Hawaiian honeycreepers in the main Hawaiian Islands, and they are the last to exclusively occupy dry forest habitat.

Mauna Kea, the highest volcano in the Pacific, sustains a broad spectrum of climatic regimes and biological communities on its long, broad slopes. Mauna Kea's snowcapped summit looms $4205 \mathrm{~m}$ above its tropical shoreline, and its flanks cover $2380 \mathrm{~km}^{2}$ in area. The structure and composition of vegetation on Mauna Kea are stratified by elevation (Gagné \& Cuddihy, 1999), as they are on other high mountain slopes in Hawai'i (Mueller-Dombois, 1981) and elsewhere. Bird communities on Mauna Kea also change in response to elevation, climate, vegetation, and other biotic factors, including alien species (Scott et al., 1986). Few studies have considered the response of Hawaiian forest bird species to resources and habitats along gradients of elevation or other environmental variables (but see Berlin et al., 2001; Hess et al., 2001). Such studies are difficult partly because Hawaiian birds no longer occur throughout the full extent of their former ranges. Most species are absent at low and mid elevations because of the devastating impacts of alien disease vectors (Warner, 1968; van Riper et al., 1986), predators (Atkinson, 1977; Tomich, 1981), and many other alien species that have reduced food resources and degraded habitats (Scott et al., 1986).

Over their historic range, Loxioides populations have disappeared from areas where introduced mosquitoes thrive, generally below 1500 m (Goff \& van Riper, 1980), and where forests have been converted to grazing land, generally below $2300 \mathrm{~m}$. Extinct for most of the twentieth century on 
Mauna Loa and Hualālai, Loxioides occupies only a small fraction of its historic range and is becoming increasingly isolated and concentrated on the western slope of Mauna Kea (Banko, 1979; Scott et al., 1984; Jacobi et al., 1996).

Loxioides derive most of their dietary and habitat requirements from Sophora chrysophylla (Salisb.) Seem. (Fabaceae), or māmane, an endemic dry forest tree species that occurs widely throughout the main Hawaiian Islands and ranges from near shoreline to tree line $(>3000 \mathrm{~m}$ elevation). Loxioides of all age classes eat almost exclusively the immature (green) seeds of Sophora, which are protected in tough fibrous pods, and flower parts (Banko et al., in press a). Sophora seeds and flower parts are also fed to nestlings, although Lepidoptera larvae are also important in their diet. Considerable strength is needed to bite through the very tough stem of the pod and to tear the pod apart in order to expose the seeds. Young Loxioides are noticeably less able than adults at foraging on pods, and adult females tend to select smaller pods than males, who are slightly larger. Loxioides also consume flowers and young leaves of Sophora and obtain insects from its pods, leaves, and branches.

Dependent as they are on Sophora, Loxioides are vulnerable to many alien species that impact Sophora resources or Sophora forests generally. Introduced browsers constitute the most important threat to Sophora (Scowcroft \& Giffin, 1983), and nearly 47,000 feral sheep (Ovis aries L.) were removed from Mauna Kea during the 1930s and 1940s to protect the forest and watershed (Bryan, 1947). Although ungulate threats have not been eliminated (Juvik \& Juvik, 1984), they have been reduced sufficiently to allow us to identify other threats (Pratt et al., 1997). Possibly because Sophora seeds contain high levels of secondary compounds (Banko et al., 2002) they seem not to be preferred foods of introduced rodents (Amarasekare, 1994). Neither do alien insects seem important in reducing the availability of seeds or flowers. However, alien insects threaten insect prey important to Loxioides. Moth larvae, particularly Cydia spp. (Tortricidae), are consumed by Loxioides of all ages, but they are especially frequent in the diet of nestlings (USGS, Unpubl. data). Although pods may protect Cydia larvae from avian predators other than Loxioides, they do not protect these larvae from introduced endoparasitoid wasps and possibly other arthropod predators and parasites (Brenner et al., in press). Loxioides also prey on other moth larvae, including Scotorythra sp. (Geometridae; USGS, Unpubl. data), which are vulnerable to alien predatory wasps and ants in addition to parasitic wasps and flies. Weeds threaten Sophora forests by increasing fire risks, suppressing seedlings, replacing native plants, and subsidizing alien insects that disrupt native insect communities (Dougill et al., in review). Small, introduced mammals prey on Loxioides (van Riper, 1980a; Pletschet \& Kelly, 1990; Pratt et al., 1997; Banko et al. in press a), and some, particularly rodents, potentially destroy seeds and seedlings of native plants.

Analysing bird densities in relation to habitat variables, Scott et al. (1984) suggested that the range of elevation is important to the distribution and abundance of Loxioides on Mauna Kea. However, the way in which an elevation gradient affects Loxioides ecology is poorly understood. We examine how a gradient of elevation affects food availability and the distribution of alien threats to food resources and habitat on the western slope of Mauna Kea, where Loxioides are concentrated. In particular, we evaluate temporal and spatial patterns of Sophora flower and seed availability to understand how Loxioides are able to persist on the western slope and to determine what habitat conditions are necessary before reintroducing Loxioides to their former range. We also examine distributions of Cydia and other insect prey in relation to introduced parasitoids and predatory insects. We also evaluate the distribution of several invasive weeds that threaten Sophora forests by changing fire regimes and suppressing Sophora regeneration. Finally, we assess distribution and abundance patterns of small mammals to consider predatory threats. However, we defer more rigorous testing of factors that affect Loxioides distribution, abundance, and behaviour to a time when we can analyse other important variables, such as extent and distribution of habitat area (i.e. more than simply breadth of elevation) and quality of habitat (e.g. tree size and canopy cover, food availability per unit of area).

\section{METHODS}

\section{Study sites}

We conducted the majority of our studies on the western slope of Mauna Kea to understand how elevation affected food availability and the distribution of alien threats in the critical core of Loxioides habitat (Fig. 1, Table 1). We also investigated some questions on the northern slope of Mauna Kea, where Loxioides restoration efforts are beginning. In addition, we studied two sites, Pōhakuloa Flats and Kīpuka 'Alalā, at lower elevation and having relatively short elevation gradients to compare with sites having greater ranges of elevation. Pōhakuloa Flats occurs on the southern slope of Mauna Kea near its boundary with Mauna Loa, the second highest of Hawai'i's five major volcanoes. Kipuka 'Alalā occurs on the north-western flank of Mauna Loa about $29 \mathrm{~km}$ from the summit of Mauna Kea. Loxioides have been absent from both Pōhakuloa Flats and Kīpuka 'Alalā for decades, but Kīpuka 'Alalā is being considered as a future reintroduction site.

We conducted studies on the western slope of Mauna Kea (1) within large units that were extensively covered by transects and (2) along transects orientated from high to low elevation (Table 1). We surveyed along transects at all other sites. Most of the data was collected at or near stations situated at $150-\mathrm{m}$ intervals along each transect. We derived elevations to the nearest $30 \mathrm{~m}$ with the 7.5 -min Data Elevation Model (DEM) in ArcView GIS. This DEM corresponded to USGS 7.5-min (1:24,000 and $1: 25,000$ scale) topographic quadrangle map series for the United States, and elevation profiles were separated by $30 \mathrm{~m}$ in Universal Transverse Mercator (UTM) projection. 


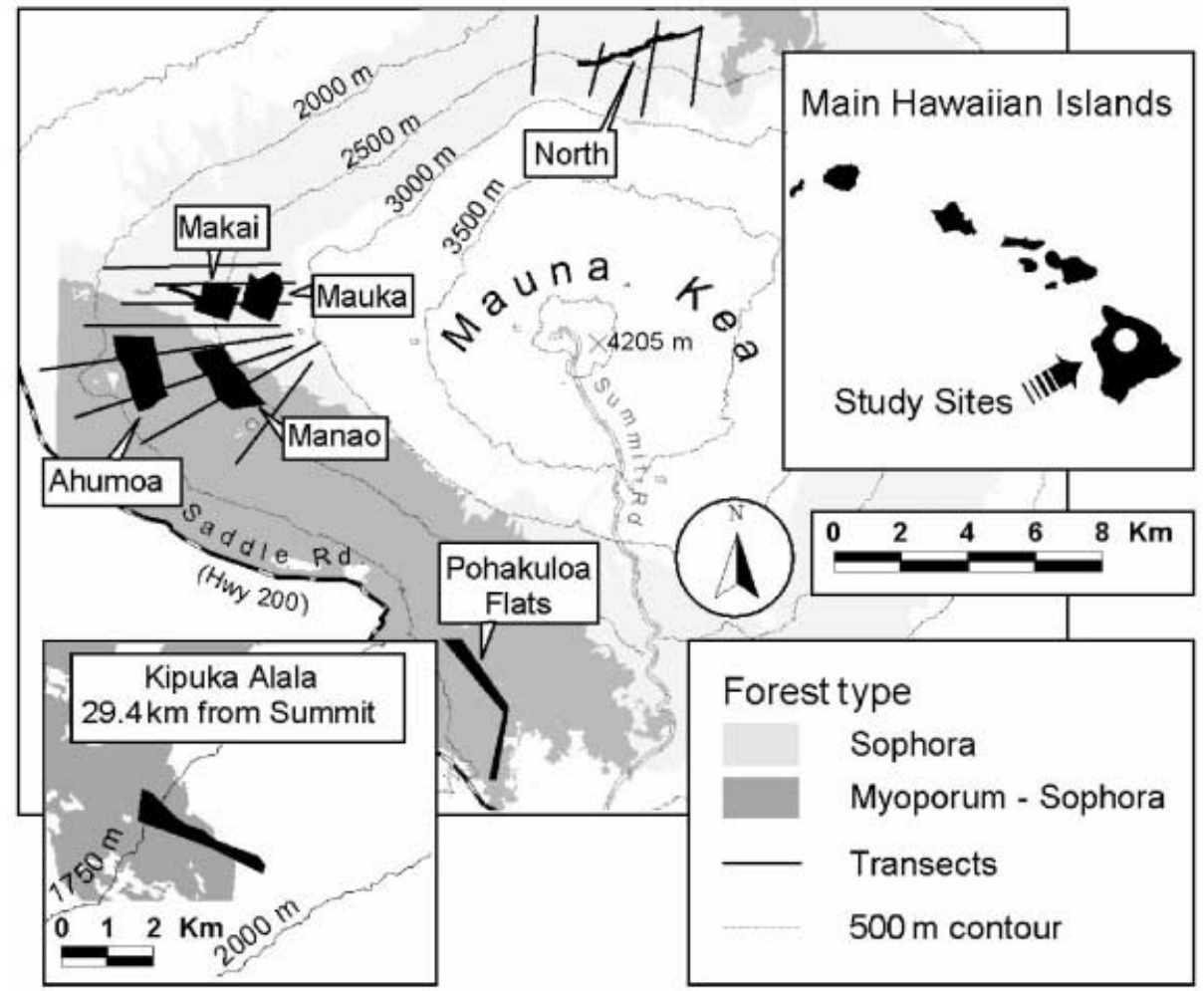

Figure I Study sites on Mauna Kea (8) and Mauna Loa (1). Studies were conducted along transects in study units (black) or Forest Transects (North: 116,118-120; West: 101103, 122-126). Sophora chrysophylla (Salisb.) Seem. (māmane) or Myoporum sandwicense A. Gray (naio) dominated the subalpine and montane forest communities included in the study.

Table I Elevation and activities conducted at nine study sites

\begin{tabular}{|c|c|c|c|c|}
\hline Region & Study Site & Median Elevation (m) & Range of Elevation $(\mathrm{m})$ & Activities ( $n$ sampling sites or units) \\
\hline \multirow[t]{5}{*}{ Mauna Kea (Western Slope) } & Ahumoa & 2132 & $2028-2235$ (207) & $\begin{array}{l}\text { Sophora* and Myoporum† phenology } \\
\text { (40); Cydia } \ddagger \text { survey and parasitism } \\
\text { (40) }\end{array}$ \\
\hline & Manao & 2418 & $2312-2523(211)$ & $\begin{array}{l}\text { Sophora and Myoporum phenology } \\
\text { (40); Cydia survey and parasitism } \\
\text { (40) }\end{array}$ \\
\hline & Makai & 2451 & $2297-2605(308)$ & $\begin{array}{l}\text { Sophora phenology (40); Cydia survey } \\
\text { and parasitism }(>40)\end{array}$ \\
\hline & Mauka & 2702 & $2589-2814(225)$ & $\begin{array}{l}\text { Sophora phenology (40); Cydia survey } \\
\text { and parasitism }(>40)\end{array}$ \\
\hline & $\begin{array}{l}\text { West Forest } \\
\text { Transects }\end{array}$ & 2383 & 1785-2981 (1196) & $\begin{array}{l}\text { Cydia parasitism (25); foliar moth } \\
\text { larvae survey and parasitism }(25) \text {; } \\
\text { Vespula } \$ \text { survey }(20) \text {; weed survey } \\
\text { (231); rodent survey (146); } \\
\text { carnivore survey }(456 \mathrm{t}-\mathrm{n})\end{array}$ \\
\hline \multirow[t]{3}{*}{ Mauna Kea (Other Slopes) } & North & 2338 & $2125-2551(426)$ & $\begin{array}{l}\text { Sophora phenology (30); Cydia survey } \\
\text { (30) and parasitism (10) }\end{array}$ \\
\hline & $\begin{array}{l}\text { North Forest } \\
\text { Transects }\end{array}$ & 2509 & 2110-2908 (798) & $\begin{array}{l}\text { Cydia parasitism (25); foliar moth } \\
\text { larvae survey and parasitism }(25) \text {; } \\
\text { Vespula survey (20); carnivore } \\
\text { survey (788 t-n) }\end{array}$ \\
\hline & $\begin{array}{l}\text { Pōhakuloa } \\
\text { Flats }\end{array}$ & 2052 & $2017-2087(70)$ & $\begin{array}{l}\text { Sophora phenology (30); Cydia survey } \\
(30) \text { and parasitism (10) }\end{array}$ \\
\hline Mauna Loa & $\begin{array}{l}\text { Kipuka } \\
\text { 'Alalā }\end{array}$ & 1813 & 1708-1917 (209) & $\begin{array}{l}\text { Sophora phenology (30); Cydia survey } \\
\text { (30) and parasitism (10) }\end{array}$ \\
\hline
\end{tabular}

"Sophora chrysophylla (Salisb.) Seem. (Fabaceae; māmane).

$\uparrow$ Myoporum sandwicense A. Gray (Myoporaceae; naio).

†ydia spp. (Tortricidae).

\Vespula pensylvanica (Saussure) [Vespidae; Western yellowjacket]. 
Vegetation at the low-elevation sites, Kīpuka 'Alalā and Pōhakuloa Flats, was montane dry forest, and at higherelevation sites on Mauna Kea the vegetation was subalpine dry forest (Gagné \& Cuddihy, 1999). Sophora was the dominant tree on the northern slope of Mauna Kea and in two study units (Mauka and Makai) on the western slope (Fig. 1; van Riper, 1980b; Scott et al., 1984; Hess et al., 1999). Myoporum sandwicense A. Gray (Myoporaceae), or naio, dominated elsewhere, although Sophora was common or abundant at all sites. Myoporum dominance in some areas may be partly an artifact of long-term browsing pressure on Sophora by feral ungulates, in particular O. aries L. (sheep) and O. musimon Pallas (mouflon sheep; van Riper, 1980b; Scowcroft \& Giffin, 1983; Hess et al., 1999). Many alien weeds have also become established in areas disturbed by feral browsers.

Fog drip from trees often supports a variety of shrubs and herbs in Hawaiian subalpine dry forest (Gagné \& Cuddihy, 1999). On the western slope of Mauna Kea, precipitation is not related to elevation in years of normal or higher rainfall, and isohyet maps indicate no clear rainfall gradient there; however, rainfall decreases with elevation in drier years (Juvik et al., 1993). Neither is there a distinct seasonal pattern to the distribution of rainfall. Long-term (58-year) rainfall records from mid elevation on the western slope of Mauna Kea reveal that June receives 10-20 mm; July and September-December receive 20-30 mm; February, April, May, and August receive $30-40 \mathrm{~mm}$; and January and March receive 40-50 mm (Juvik et al., 1993).

\section{Phenology of Sophora and Myoporum and availability of plant food resources}

We assessed Sophora phenology every month during 19922001 by examining for $6.2 \mathrm{~min} \pm 4.64$ SD (range $=$ 1-87 $\mathrm{min} ; n=17,499$ ) individually marked Sophora trees ( $n=17,600)$ at stations situated $150 \mathrm{~m}$ apart along transects in study units on the western slope of Mauna Kea: Ahumoa ( $n=20-40$ trees/month), Manao $(n=20-40)$, Makai $(n=31-55)$, and Mauka $(n=25-31)$. Results were stratified by elevation: Low $=2028-2297 \mathrm{~m}(n=19-41$ trees/ month), Mid = 2303-2540 m ( $n=24-81)$, High $=2559$ $2814 \mathrm{~m}(n=31-64)$. We also evaluated tree phenology each month at two sites with short elevation gradients, Pōhakuloa Flats ( $n=22-30$ trees/month; 70-m gradient) and Kipuka 'Alalā $(n=28-30 ; 209 \mathrm{~m})$, and two sites with long gradients, West (Ahumoa, Manao, Makai, and Mauka combined; $n=87-182 ; 786 \mathrm{~m})$ and North $(n=30 ; 426 \mathrm{~m})$ during June 1997-December 1998. We quantified the reproductive effort of trees in two ways to allow different analyses of phenological trends. At each tree therefore we recorded numbers of flowers and pods (counted individually or in groups of three to five pods) and the category of percent $(0$, $\leq 1,2-5,6-10,11-25,26-50,51-75,76-100 \%)$ of live branch tips with at least one flower or pod. We counted flowers that were open (available to pollinators), and we counted pods in which seeds were expanded to $\geq 3 \mathrm{~mm}$ diameter (acceptable to Loxioides). We assessed Myoporum phenology in a similar manner by sampling forty marked trees each month at Ahumoa and Manao during December 1991-September 1995. We counted open flowers and fruit that were green (immature) or white (ripe) but not brown and dried (not eaten by Loxioides).

\section{Availability of Cydia larvae}

To assess availability of Cydia larvae we collected two randomly selected pods (each with at least one seed measuring $\geq 3 \mathrm{~mm}$ diameter) from each Sophora tree when we assessed phenology during March 1996-September 2001. If pods were not available on the tree being assessed, they were picked from the closest tree with pods. When pods were scarce in an area, we picked at least two pods per tree (thus, we sampled at elevations somewhat higher or lower than delineated by the three Sophora phenology strata). We determined Cydia presence by dissecting each pod and recording number of seeds $(\geq 3 \mathrm{~mm}$ diameter) per pod, number of seeds eaten by larvae, and number of Cydia larvae present.

\section{Availability of moth larvae on Sophora foliage}

We sampled moth larvae on Sophora foliage along Forest Transects on the western and northern slopes of Mauna Kea during 1999 (February-April and October-November) and 2000 (March and September-October). We collected near five stations separated by 150 m elevation between 2200 and $2800 \mathrm{~m}$. Samples were taken during 0800-1600 h on days with no heavy cloud overcast or rain. Larvae were collected by shaking Sophora branches vigorously for 1-min intervals over a $1-\mathrm{m}^{2}$ sheet. We sampled several trees (each $\geq 2 \mathrm{~m}$ tall by $\geq 2 \mathrm{~m}$ canopy diameter) within $100 \mathrm{~m}$ of the station for a total of $1 \mathrm{~min}$. We repeated this procedure up to seven times at each station, depending on tree availability. Results of preliminary sampling revealed that $7 \mathrm{~min}$ was usually necessary to collect at least one larva. We checked the collection sheet between each 1-min sampling period. Larvae were placed in dry vials containing Sophora leaves and kept cool until they could be transferred into individual rearing containers in the laboratory at Kilauea Field Station (KFS), Hawai'i Volcanoes National Park (1200 m elevation).

\section{Threats to insect prey}

Parasitoids

To determine the rate of parasitism of Cydia larvae, we (1) collected Sophora pods that contained Cydia by noting the presence of silk caps that were spun over larval emergence holes, and (2) reared either moths or parasitoids from these pods in the laboratory at KFS. In 1996-97, we collected pods from seven sites: all four units on western Mauna Kea (Ahumoa, Manao, Makai, Mauka), North, Pōhakuloa Flats and Kipuka 'Alalā, representing an elevation gradient extending 1106 m (1708-2814 m). During 1998-2001, we stratified sampling along Forest Transects on the western and northern slopes of Mauna Kea according to five strata of 
elevation ranging from 2200 to $2800 \mathrm{~m}$ and separated by $150 \mathrm{~m}$. We collected ten pods from each study site each month from April 1996 to April 1997. During 1998-2001, we collected twenty-five pods quarterly (February, May, August, November) from each elevation stratum on the western and northern slopes.

We evaluated the rate of parasitism of moth larvae collected from Sophora foliage along Forest Transects on the western and northern slopes of Mauna Kea during January 1998-October 2000 (see methods above) by rearing the larvae until an adult moth or parasitoid emerged or until the larvae died.

From larvae collected from Sophora pods or foliage, we reared moths or parasitoids at ambient temperature and humidity in the laboratory. Each pod or sprig of fresh foliage (foliage renewed at least twice per week) was placed in a $240-\mathrm{mL}$ plastic container fitted with a screen lid to allow air circulation and prevent moulding. Containers were inspected daily for the emergence of moths or parasites. Pods from which no insects emerged were dissected after 3 months and the fate of each larva was recorded (e.g. alive, dead, missing, never present). Live larvae were returned to their pods to finish development. We calculated the rate of parasitism as the percentage of moth larvae that produced a parasitic insect (moth larvae that died of unknown causes were not included), and we used linear regression after pooling data for both slopes (in the case of specimens collected from West and North Forest Transects) to analyse the relationship between parasitism rates and elevation.

\section{Predatory wasps and ants}

We monitored Vespula pensylvanica (Saussure) [Vespidae], or Western yellowjacket, activity monthly during 19982001 along Forest Transects on the western and northern slopes of Mauna Kea at five strata of elevation between 2200 and $2800 \mathrm{~m}$, each separated by $150 \mathrm{~m}$ (the same as used for foliar insect surveys and Cydia parasitism studies). We used Seabright ${ }^{\mathrm{TM}}$ brand yellowjacket traps (twenty traps per slope) baited with heptyl buterate, a known attractant (Davis et al., 1969; MacDonald et al., 1973). A cotton swab was inserted $1 \mathrm{~cm}$ into a $0.5-\mathrm{mL}$ eppendorph tube filled with $75 \%$ heptyl buterate, which was then placed into the trap. Traps were suspended 1-2 $\mathrm{m}$ high from a tree branch at each sampling station.

We surveyed for ants (Formicidae) along transects that ran upslope from Saddle Road (1850-2000 m elevation) to c. $2400 \mathrm{~m}$ on the south-western slope of Mauna Kea during June-July and November-December in both 1999 and 2000. Transects were spaced $500 \mathrm{~m}$ apart near Saddle Road and converged to $200 \mathrm{~m}$ at their upslope terminus. Stations were spaced at $200 \mathrm{~m}$ along each transect. We sampled ants using a method similar to Wetterer et al. (1998) by placing three baits of approximately $2 \mathrm{~g}$ of oilpacked tuna fish on clear plastic discs $(6.5 \mathrm{~cm}$ diameter on the ground within $10 \mathrm{~m}$ of each station. We revisited stations after $2-4 \mathrm{~h}$ to record the species and approximate number of ants visiting each bait.

\section{Distribution of weeds}

We estimated percentage cover of alien and native grass species at 231 plots located randomly within $40 \mathrm{~m}$ of stations spaced at $150-\mathrm{m}$ intervals along eight Forest Transects on the western slope of Mauna Kea during 1999-2001. Percentage cover in each plot was determined by pole intercept along four parallel $40-\mathrm{m}$ transects spaced at $10-\mathrm{m}$ intervals. Grass was sampled at $1-\mathrm{m}$ intervals along each transect (forty-one points per transect). At each sample point, a $2-\mathrm{m}$ pole was placed vertically and we recorded grass species touching the pole. A species touching the pole more than once was recorded as a single entry. Results were stratified into the same bands of elevation as used for Sophora phenology: Low (2028-2297 m), Mid (2303-2540 m), and High (2559-2814 m).

Two weed surveys were conducted: Survey 1 (June 1999) and Survey 2 (November 1999). We based Survey 1 on the same eight Forest Transects used to determine the cover of native and alien grasses on the western slope. Survey 2 sampled an area below Survey 1 and was conducted along transects used for ant surveys (see methods above). Field methods were similar in the two surveys; we recorded the presence of the invasive vine, Delairea odorata Otto ex Walp. (Asteraceae; Cape ivy), and a fire-promoting grass, Pennisetum setaceum, Chiov. (Poaceae; fountain grass), in an elliptical area $\left(11,775 \mathrm{~m}^{2} ; 25 \times 150 \mathrm{~m}\right)$ centred on each of 471 stations.

\section{Distribution of introduced small mammals}

We surveyed rodents with snap-traps during three sessions (June 2000, January 2001, June 2001) in vegetation survey plots on four Forest Transects on the western slope of Mauna Kea. We placed two rat traps and four mouse traps among or near vegetation or other cover where small mammals would be expected to occur. We placed two mouse traps $2 \mathrm{~m}$ apart with a rat trap between them at the centre of the north and south vegetation plot boundaries. After 3 days of pre-baiting with shredded coconut, traps were baited with coconut chunks and set for four days; traps were checked daily and rebaited and reset as necessary. This scheme yielded four trap-nights per trap or twenty-four trap-nights (mouse and rat traps) per station. Capture rates of Mus musculus Linnaeus (house mouse) were calculated using the number of trap-nights for both mouse and rat traps, because mice were often caught in rat traps. Capture rates of Rattus rattus Linnaeus (roof, ship, or black rat) were calculated using only rat trap-nights. To determine more accurately our sampling effort, we corrected the trapping interval (number of trap-nights) to account for sprung traps, using the formula developed by Beauvais \& Buskirk (1996): trapinterval $=($ traps $\times$ intervals $)-($ sprung traps $\times 0.5)$. We pooled results of all three surveys and stratified by elevation: Low (1785-2180 m), Mid (2180-2579 m), High (2596-2981 m). 
We determined the distribution and relative abundance of two introduced carnivorous species, Felis catus Linnaeus (house cat) and Herpestes auropunctatus Hodgson (small Indian mongoose), by trapping (with removal) along Forest Transects and roads during five sessions on the western $(n=3)$ and northern $(n=2)$ slopes of Mauna Kea. Trapping occurred over 1244 trap-nights: West [28 July-20 August 1998 (329 t-n); 16 June-15 July 1999 (170 t-n); 19-29 September 2000 (289 t-n)]; North [30 April-29 May 1998 (199 t-n); 10-23 September 1998 (257 t-n)]. Trapped animals were killed in all sessions except on the western slope during September 2000, when Felis were radio-tagged for studies of home range. We separated trapping results into the same three strata as used for rodent surveys. Tomahawk ${ }^{\mathrm{TM}}$ model 106 live traps $(6 \times 23 \times 23 \mathrm{~cm})$ were baited with fish-flavoured canned cat food, or occasionally with canned sardines and mackerel, and were checked daily. All three baits seemed effective. Traps were wired open during weekends and set to catch animals during the week.

\section{Analysis of data}

We did not conduct experiments or test a priori hypotheses concerning the effects of elevation or other environmental factors on the availability of Loxioides foods, the distribution of alien species that threaten Loxioides or its habitat, or Loxioides distribution and behaviour. Instead, we have interpreted the data in an exploratory, descriptive fashion to provide a general ecological framework for understanding the major themes of our long-term project, to guide more detailed analyses in the future, and to facilitate conservation efforts. We rely mainly on graphical analysis and provide 95\% Confidence Intervals (CI), coefficients of variation $(\mathrm{CV})$, and Standard Errors (SE) around means to help interpret the magnitude of their differences and variation and to identify trends. Descriptive statistics and graphs were generated on Microsoft Excel ${ }^{\mathrm{TM}}$ spreadsheets.

\section{RESULTS}

\section{Phenology of Sophora and Myoporum and availability of plant food resources}

\section{Sophora}

Sophora flowering patterns varied with elevation on the western slope of Mauna Kea over the 10-year sampling period (Fig. 2a). Flowering pulsed earlier and with greater intensity at high elevation before moving unevenly downslope. The wave of flowering moved downslope at about $131 \mathrm{~m} \mathrm{month}^{-1}$ such that peaks of flowering at the midpoints of high and low elevation strata $(2687-2163 \mathrm{~m})$ were separated by 4 months. The proportion of trees that flowered heavily $(>25 \%$ of tree branch tips contained at least one flower) in each elevation stratum peaked most sharply at high elevation in September and pulsed distinctly at low elevation in January. However, mid-elevation trees flowered with less seasonality; instead they flowered heavily in two modest pulses coincident with the stronger peaks
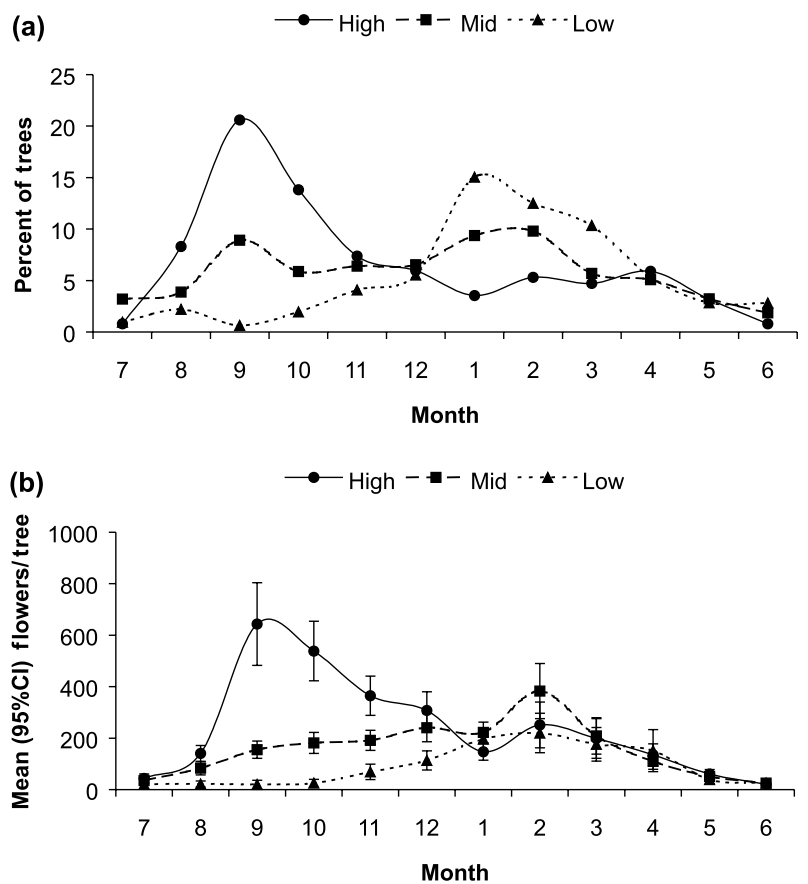

Figure 2 (a) Sophora chrysophylla flower phenology on the western slope of Mauna Kea in three strata of elevation (Low $=2028-2297$ $\mathrm{m}$ [median $2163 \mathrm{~m} ; n=19-41$ trees $/$ month], Mid $=2303-2540 \mathrm{~m}$ [median 2422; $n=24-81$ ], High $=2559-2814 \mathrm{~m}$ [median $2687 \mathrm{~m} ; n=31-64])$. In each stratum, percentages of trees with heavy flower crops ( $>25 \%$ of branch tips with $\geq 1$ flower) are plotted for each month (July = 7) for the period 1992-2001. Surges of heavy flowering at high and low elevations were separated by 4 months. (b) Mean ( $\pm 95 \%$ Confidence Interval) number of flowers per Sophora tree on the western slope of Mauna Kea in three strata of elevation (as in Fig. 2a) during 1992-2001. Trees at low elevation produced their largest flower crops 5 months later than trees at high elevation, but trees at mid elevation produced flowers relatively gradually and without a distinct seasonal pulse.

observed at both high and low elevations. Within each stratum of elevation, $10 \%$ or more of the trees flowered heavily for only 1-3 months, but over the entire $786-\mathrm{m}$ span of elevation, heavy flowering occurred among $\geq 10 \%$ of the trees in one or more strata for 5 months (Fig. 2a).

Monthly estimates of flower numbers on individual trees generally confirmed that high-elevation trees flowered profusely before trees at lower elevations (Fig. 2b). Highelevation trees produced many more flowers in September, as expected. Mid-elevation trees slowly increased flower production during September-December and pulsed moderately in February. There was, however, no sudden increase in flower crops among low-elevation trees; instead, trees produced larger numbers of flowers steadily from November to February, after which flowering tapered off gradually.

Pod production followed flowering by about 4 months, but seasonal trends were more extended than for flowers. Individual pods remained green on the tree (and edible to Loxioides) for $>4$ months, whereas flowers persisted for 
$<1$ month (USGS, Unpubl. data); thus, 1 month of flowering resulted in $>4$ months of pods on the same tree. Nevertheless, pod production surged at 1-2-month intervals in each stratum of elevation. Pod production was most intense in February at high elevation, April at mid elevation, and May at low elevation (Fig. 3a). Crops of pods per tree were larger during November-May at high elevation, March-June at mid elevation, and March-July at low elevation (Fig. 3b). Within each stratum of elevation, at least $10 \%$ of the trees bore large pod crops ( $>25 \%$ of tree branch tips contain $\geq 1$ pod) for $4-5$ months, but over the entire 786-m span of elevation, heavy pod production among $\geq 10 \%$ of the trees in one or more strata extended for 7 months (Fig. 3a). Considering separately all months of the 10 -year study, large pod crops were produced by $\geq 10 \%$ of the trees within each elevation stratum during $23-28 \%$ of the 120-month period; however, large pod crops were

\section{(a)}

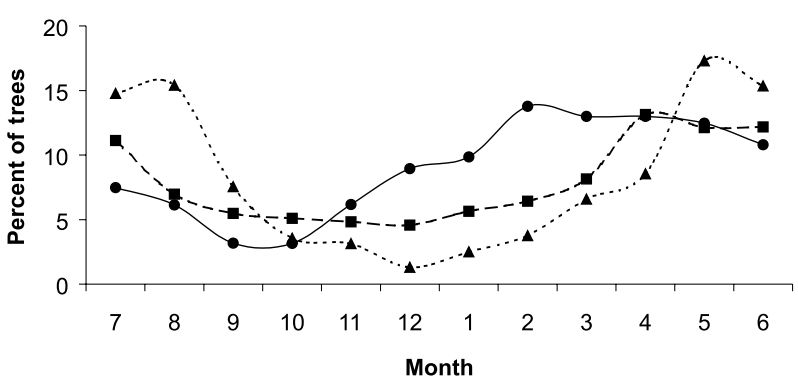

(b)

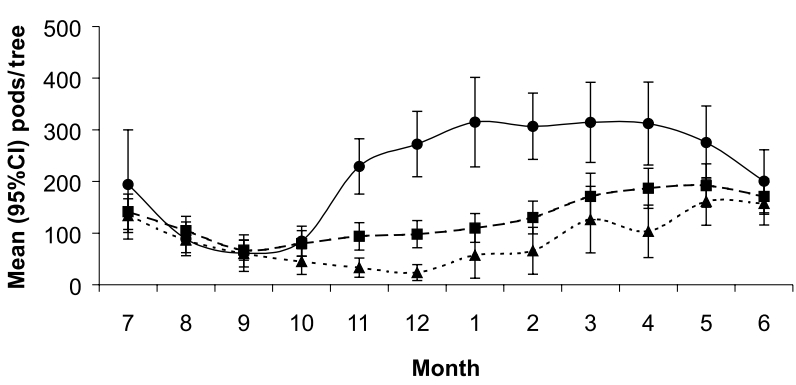

Figure 3 (a) Sophora chrysophylla pod phenology on the western slope of Mauna Kea in three strata of elevation (Low $=2028-2297$ $\mathrm{m}$ [median $2163 \mathrm{~m} ; n=19-41 \mathrm{trees} / \mathrm{month}], \mathrm{Mid}=2303-2540 \mathrm{~m}$ [median 2422; $n=24-81$ ], High $=2559-2814 \mathrm{~m}$ [median $2687 \mathrm{~m} ; n=31-64])$. In each stratum, percentages of trees with heavy pod crops ( $>25 \%$ of branch tips with $\geq 1$ pod) are plotted for each month (July $=7$ ) for the period 1992-2001. Pods remain green on trees for $>4$ months, hence trends in seasonal availability are dampened. Nevertheless, waves of high pod production sweep downslope starting with trees at high elevation in February and reaching mid and low elevations by April and May. (b) Mean ( $\pm 95 \%$ Confidence Interval) number of pods per Sophora tree on the western slope of Mauna Kea in three strata of elevation [as in (a)] during 1992-2001. As predicted from the strong seasonal pulse of flowering (see Fig. 2a, b), high elevation trees bear more pods over more months than do trees at lower elevations. available in at least one stratum along the entire span of elevation during $44 \%$ of the 120 -month period.

Trees bearing heavy crops of flowers and pods were represented about equally in each stratum of elevation. Proportions of the population that bore heavily were: $6.7 \%$ (flower) and $9.0 \%$ (pod) at high elevation; 5.4\% (flower) and $8.0 \%$ (pod) at mid elevation, and $5.8 \%$ (flower) and $8.3 \%$ (pod) at low elevation. Conversely, flower and pod crops declined in size with elevation. Flowers per tree averaged $237 \pm 22$ (95\% CI; $n=31-64$ trees/month; high elevation), $157 \pm 14 \quad(n=24-81$; mid elevation), and $89 \pm 12\left(n=19-41\right.$; low elevation; $R^{2}=0.99, F=680$, $P=0.02$ ). Following the trend for flowers, mean pods per tree averaged $222 \pm 20(95 \% \mathrm{CI} ; n=6107$ trees; high elevation), $129 \pm 9$ ( $n=7729$; mid elevation), and $88 \pm 11\left(n=3764\right.$; low elevation; $R^{2}=0.95, F=21.2$, $P=0.14)$.

Average monthly crop size varied greatly among trees within each stratum of elevation, resulting in food being available longer than if trees had been more synchronous. Although average annual crop size per tree declined with elevation, low-elevation trees sometimes produced prodigiously, making them the most variable in terms of production [i.e. low-elevation trees generally had the largest coefficient of variation (CV) values; Table 2]. Overall, average crop sizes varied about as much within each stratum of elevation as they did over the whole range of elevation (Table 2).

In each stratum of elevation, at least some trees were heavily laden with flowers or pods in any month (all years combined). Heavy flowering occurred among $\geq 10 \%$ of the trees in each stratum during $17-22 \%$ of the 10 -year period, but trees failed to flower heavily $34-59 \%$ of the time (Table 3). In contrast, over the entire range of elevation (all three strata combined), heavy flowering occurred among $\geq 10 \%$ of the trees in any one of the strata $36 \%$ of the time, and trees failed to flower heavily only $22 \%$ of the 10 -year period. Heavy pod production occurred among $\geq 10 \%$ of the trees of each stratum $23-28 \%$ of the 10 -year period, but trees failed to bear heavily $28-55 \%$ of the time. Heavy pod crops were borne by $\geq 10 \%$ of the trees in at least one of the three strata $44 \%$ of the time, and trees failed to bear heavily only $16 \%$ of the time over the whole range of elevation.

Sophora flowers and pods were available longer at sites with substantial elevation gradients (Figs 4 and 5). Heavy flowering ( $>25 \%$ of branch tips) occurred among at least $10 \%$ of the population $0-21 \%$ of the time ( $n=19$ months) at the two sites with modest gradients (70 and $209 \mathrm{~m}$ ), whereas flowering was heavy $21-26 \%$ of the time at the two sites with substantial gradients (426 and $786 \mathrm{~m}$ ). Similarly, $\geq 10 \%$ of the trees bore a heavy pod crop $37-47 \%$ of the time where the range of elevation was short and $37-63 \%$ of the time where it was long. In addition, populations of trees distributed along modest gradients bore flower and pod crops in more distinct seasonal pulses, and pods were absent $6-21 \%$ of the time. Where gradients were larger, flowers and pods were available throughout the 19 -month period and with less distinct seasonality. 
Table 2 Coefficient of variation (CV) values for monthly and annual means of pods per Sophora tree during 10 years of sampling in three strata of elevation: Low $=2028-2297 \mathrm{~m}(n=19-41$ trees/month), Mid $=2303-2540 \mathrm{~m}(n=24-81)$, High $=2559-2814 \mathrm{~m}(n=31-64)$. CV values (\%) allow comparisons of variability in different populations that are independent of the magnitude of their means, and larger CV values indicate more variation (Sokal \& Rohlf, 1981, pp. 58-59)

\begin{tabular}{|c|c|c|c|c|c|c|c|c|c|c|c|c|c|}
\hline \multirow[b]{2}{*}{ Stratum } & \multicolumn{12}{|c|}{ Month } & \multirow[b]{2}{*}{ Annual } \\
\hline & 1 & 2 & 3 & 4 & 5 & 6 & 7 & 8 & 9 & 10 & 11 & 12 & \\
\hline High & 325 & 240 & 283 & 296 & 294 & 351 & 625 & 421 & 658 & 392 & 267 & 265 & 351 \\
\hline Mid & 336 & 318 & 341 & 262 & 285 & 261 & 317 & 338 & 376 & 401 & 365 & 341 & 327 \\
\hline Low & 706 & 628 & 464 & 420 & 259 & 240 & 221 & 254 & 391 & 496 & 510 & 579 & 400 \\
\hline All & 402 & 313 & 336 & 314 & 294 & 301 & 496 & 354 & 487 & 414 & 344 & 346 & 370 \\
\hline
\end{tabular}

Table 3 Percentage of months $(n=120)$ during 1992-2001 when $\geq 10 \%$ of Sophora trees within three elevation strata bore heavy crops of flowers or pods (flowers or pods on $>25 \%$ of all live branch tips) or when no trees bore heavily. Heavy crops of flowers or pods were produced by $\geq 10 \%$ of trees in at least one of the three strata in All Strata. Flowers and pods were assessed in each stratum every month: Low $=2028-2297 \mathrm{~m}(n=19-41$ trees/month $), \mathrm{Mid}=2303-2540 \mathrm{~m}(n=24-81)$, High $=2559-2814 \mathrm{~m}(n=31-64)$

\begin{tabular}{lllll}
\hline & Low & Mid & High & All strata \\
\hline Heavy flower crop \% $(n$ months) & $17 \%(20)$ & $22 \%(26)$ & $21 \%(25)$ & $36 \%(43)$ \\
No trees with heavy flower crop & $59 \%(70)$ & $34 \%(41)$ & $43 \%(52)$ & $22 \%(26)$ \\
Heavy pod crop \% $(n$ months) & $23 \%(27)$ & $28 \%(34)$ & $27 \%(32)$ & $44 \%(53)$ \\
No trees with heavy pod crop & $55 \%(65)$ & $28 \%(34)$ & $31 \%(37)$ & $16 \%(19)$ \\
\hline
\end{tabular}

\section{Myoporum}

Myoporum phenology was not influenced obviously by elevation along the relatively short gradient we examined (Fig. 6). Heavy flowering ( $>25 \%$ of branch tips with flowers) occurred in all months, but flowering peaked during June-July at both high (median $2418 \mathrm{~m}$ ) and low (2132 m) elevation sites and increased again more modestly during December-February at the high site. Fruit remained on trees much longer than did flowers; thus, fruit was available at high, stable levels throughout the year at both sites.

\section{Availability of Cydia larvae}

Cydia larvae abundance was related to Sophora pod availability, although the incidence of Cydia per pod was higher when pods were scarce, apparently because egglaying by moths was concentrated on fewer substrates. Cydia prevalence in pods increased with elevation in terms of abundance (Cydia per pod) and feeding activity (number and percentage of seeds consumed per pod; Fig. 7; also see Brenner et al., in press). Peaks in Cydia per pod in each stratum of elevation were separated by several months when
Figure 4 Sophora chrysophylla flower phenology at two sites with small gradients of elevation (A and B) and two sites with large gradients $(\mathrm{C}$ and $\mathrm{D}) . \mathrm{A}=$ Kipuka 'Alalā (209-m range of elevation). $\mathrm{B}=$ Pōhakuloa Flats (70-m range). $\mathrm{C}=$ West (Ahumoa, Manao, Makai, Mauka; 786-m range). $\mathrm{D}=$ North (426-m range). Levels of flowering depicted are None, Moderate $(\leq 25 \%$ of branch tips with $\geq 1$ flower) and Heavy ( $>25)$. Percentages of trees in each category of flowering are indicated on the $y$-axis. Trees flowered more seasonally at sites with shorter elevation gradients. (a) $26-100 \% \square 1-25 \% \square 0 \%$

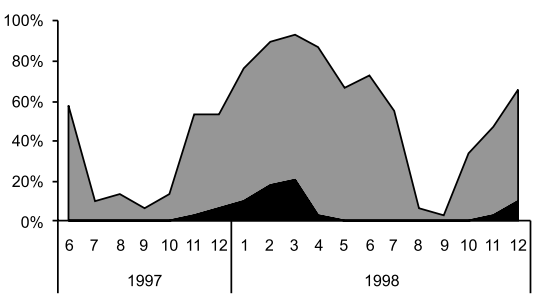

(c)

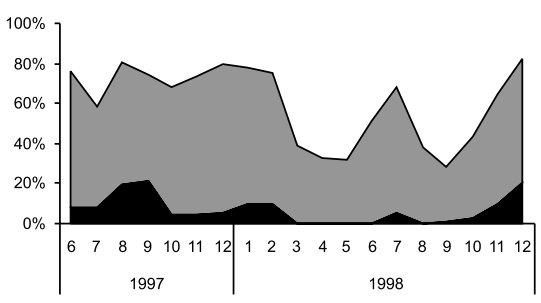

(b)

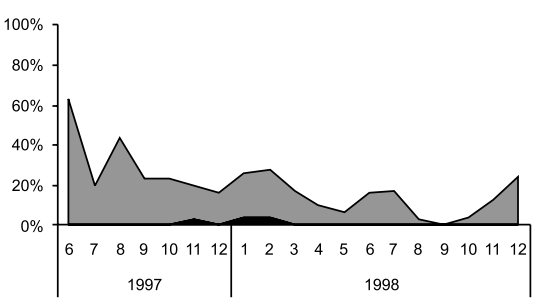

(d)

- $26-100 \% \square 1-25 \% \square 0 \%$

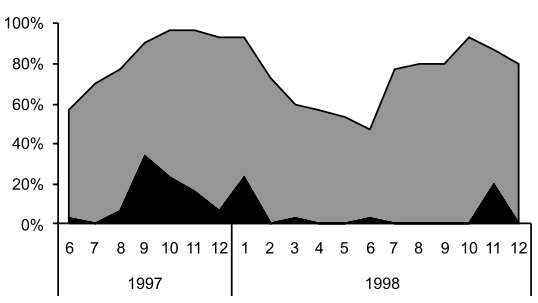


(a) - $26-100 \% \square 1-25 \% \square 0 \%$

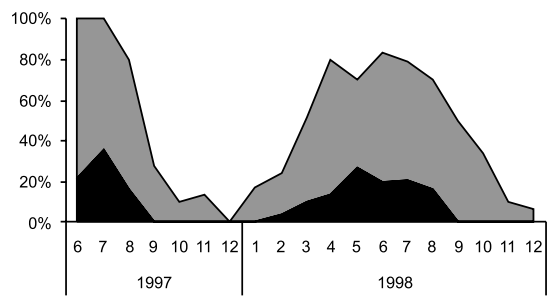

(c)

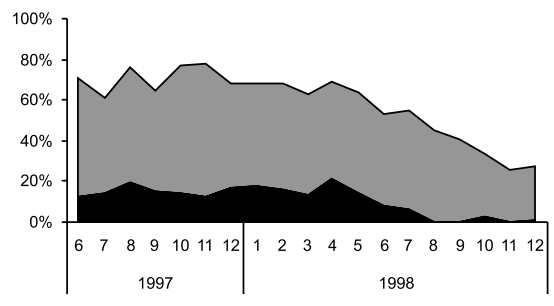

(b)

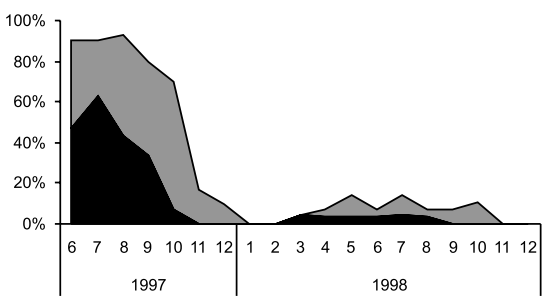

(d)

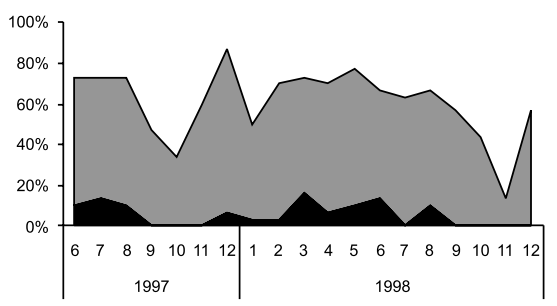

Figure 5 Sophora chrysophylla pod phenology at two sites with small gradients of elevation (A and $\mathrm{B})$ and two sites with large gradients $(\mathrm{C}$ and $\mathrm{D})$. $\mathrm{A}=$ Kipuka 'Alalā (209$\mathrm{m}$ range of elevation). $\mathrm{B}=$ Pōhakuola Flats (70-m range). $\mathrm{C}=$ West (Ahumoa, Manao, Makai, Mauka; 786-m range). $\mathrm{D}=$ North (426-m range). Levels of pod production depicted are None, Moderate $(\leq 25 \%$ of branch tips with $\geq 1$ pod) and Heavy ( $>25$ ). Percentages of trees in each category of pod production are shown on the $y$-axis. Trees produced pods more seasonally at sites with shorter elevation gradients, whereas pods were more generally distributed throughout time at sites with longer gradients.

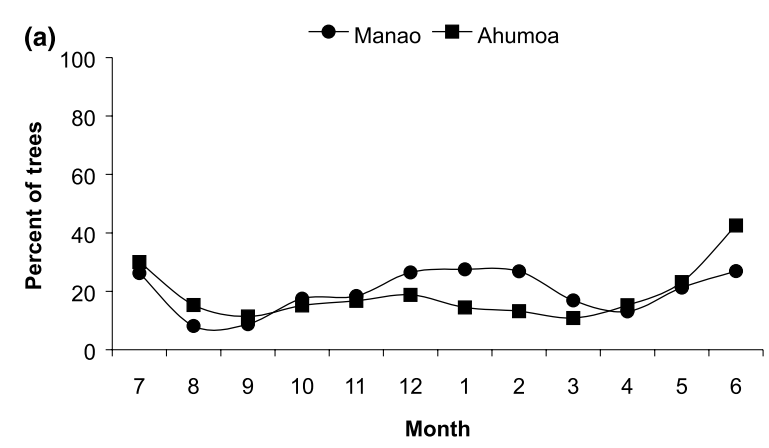

(b)

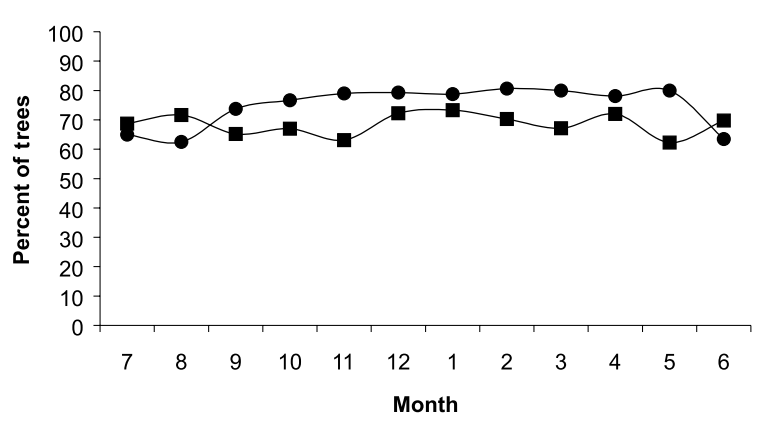

Figure 6 (a) Myoporum sandwicense flower phenology at Ahumoa (median elevation $2132 \mathrm{~m}$ ) and Manao (median elevation $2418 \mathrm{~m}$ ) study units on the western slope of Mauna Kea. In each stratum, the average percentage of trees with heavy flower crops ( $>25 \%$ of branch tips with $\geq 1$ flower) are plotted for each month (July $=7$ ) for the period December 1991-September 1995. The proportion of trees that were flowering heavily was relatively consistent through time.

(b) Myoporum fruit phenology at Ahumoa and Manao study units on the western slope of Mauna Kea. In each stratum, the average percentage of trees with heavy fruit crops ( $>25 \%$ of branch tips with $\geq 1$ fruit) are plotted for each month (July $=7$ ) for the period December 1991-September 1995. The proportion of trees that were fruiting heavily was high and relatively constant through time. data for all years were pooled (Fig. 8). However, seasonal trends in Cydia abundance were somewhat obscured and complicated by their relationship with pod abundance.

\section{Availability of moth larvae on Sophora foliage}

Moth larvae collected from Sophora foliage were more abundant at higher elevations on both the western and northern slopes of Mauna Kea (Fig. 9). The numbers of

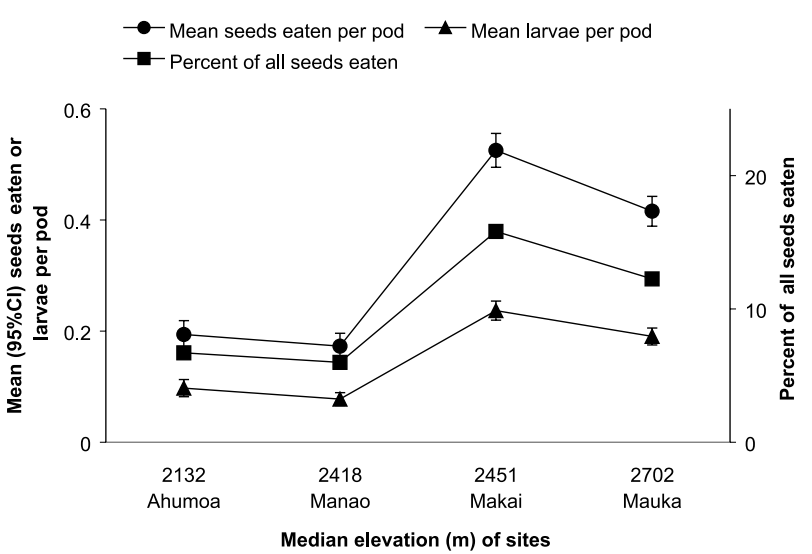

Figure 7 Cydia spp. larvae abundance (larvae per pod) and feeding activity at four sites on the western slope of Mauna Kea. The mean $( \pm 95 \% \mathrm{CI})$ number of seeds eaten per pod and mean $( \pm 95 \% \mathrm{CI})$ percentage of seeds eaten are shown in relation to elevation. During monthly Sophora phenology assessments from March 1996 to September 2001, two pods were collected at each tree (or neighbouring tree if necessary) and dissected to determine the number of Cydia, intact seeds, and eaten seeds (partially consumed seeds or presence of frass produced by larvae). A total of 12,084 pods were examined $($ Ahumoa $=1837$; Manao $=2278$; Makai $=$ 4157; Mauka $=3812$ ). Larvae were more abundant and they ate a greater proportion of seeds per pod at higher elevations. 


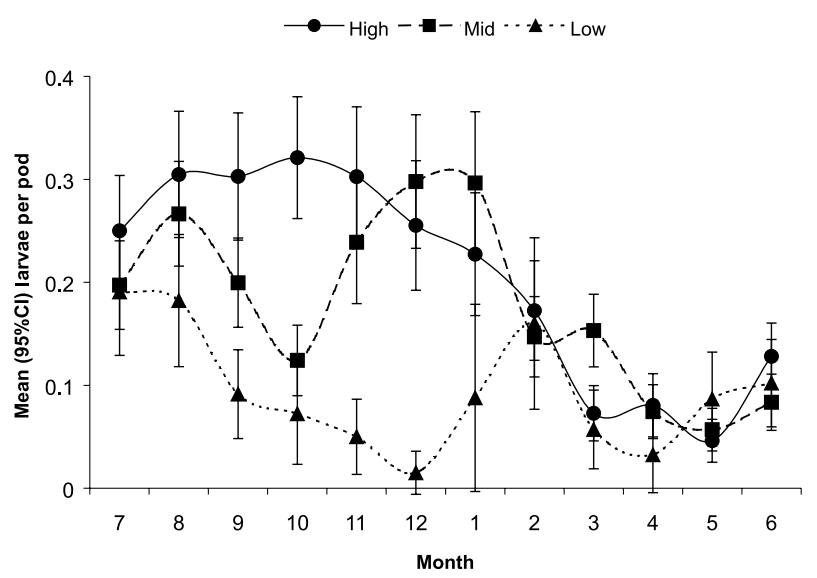

Figure 8 Cydia spp. larvae abundance (larvae per pod) in three strata of elevation on the western slope of Mauna Kea during March 1996-August 2001. Mean ( $\pm 95 \%$ CI) Elevation strata are the same as for Sophora phenology [Low $=2028-2297 \mathrm{~m}$ (median $2163 \mathrm{~m}$ ), Mid = 2303-2540 m (median $2422 \mathrm{~m})$, High $=2559-2814 \mathrm{~m}$ (median $2687 \mathrm{~m}$ )]. Two Sophora pods were collected at each tree (or a neighbouring tree if necessary) that was assessed monthly for phenology and dissected to determine the number of Cydia present (Low $n=57-236$ pods/month; Mid $n=344-578$; High $n=$ 284-468). Seasonal patterns of larvae abundance are complicated by the relationship with pod abundance, but Cydia are generally more prevalent earlier at high elevations and later at low elevations.

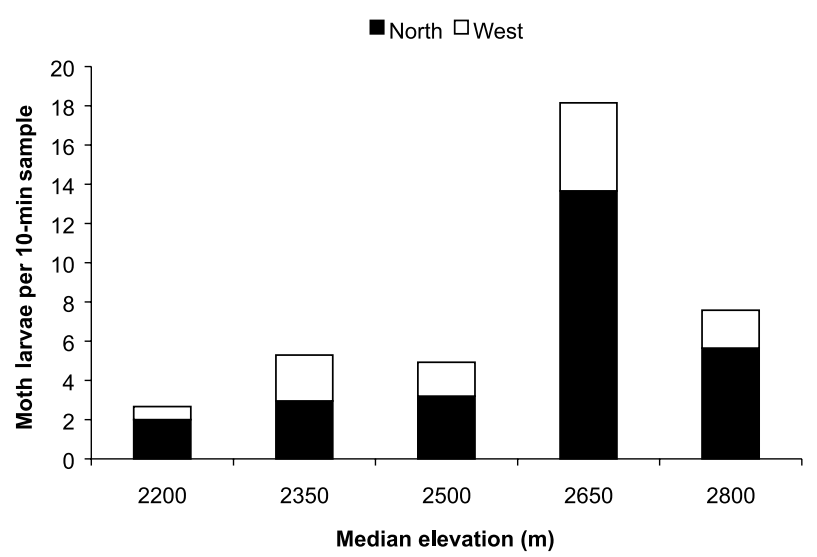

Figure 9 Numbers of Lepidoptera larvae collected from Sophora foliage during 10-min sessions. Foliage of several trees was beaten over a collecting sheet during 1-min sessions for a total of $10 \mathrm{~min}$ at five strata of elevation on the northern and western slopes during spring and fall in 1999 and 2000. Larvae on both slopes were more abundant at higher elevations.

larvae collected per minute of sampling peaked at $2650 \mathrm{~m}$ elevation and were lowest at $2200 \mathrm{~m}$. An undescribed species of Scotorythra (Geometridae; M. Heddle, U. California, Berkeley, Pers. comm.) was most frequently collected, and Peridroma albiorbis (Noctuidae) comprised the remainder of the sample.

\section{Threats to insect prey}

Parasitoids

From seven species of Cydia found in Sophora pods in 1997, we reared three alien species of Ichneumonidae, Pristomerus hawaiiensis Perkins, Diadegma blackburni (Cameron), and Calliephialtes grapholithae (Cresson), and a species of Eulophidae, Euderus metallicus (Ashmead), which may be native (this study; Brenner et al., in press). Overall, 44\% (147/335) of Cydia larvae were parasitized. P. hawaiiensis accounted for $53 \%(78 / 147)$ of the parasitism (despite what its nomenclature suggests, $P$. hawaiiensis is thought to be alien to Hawai' $i)$. Overall parasitism rates decreased as elevation increased $\left(R^{2}=0.87, F=34.7, P=0.002\right)$, ranging from $94 \%$ at $1813 \mathrm{~m}$ to $21 \%$ at $2702 \mathrm{~m}$ (also see Brenner et al., in press). Therefore, parasitism was variable at sites with substantial ranges of elevation, such as on the western and northern slopes of Mauna Kea; however, few larvae escaped parasitism at the two low elevation sites with little range of elevation (Fig. 10).

During 1998-2001, the same four wasp species parasitized Cydia as in 1997, and parasitism was 40\% (322/803) when data were pooled for western and northern slopes of Mauna Kea (2200-2800 m elevation). E. metallicus accounted for $38 \%(121 / 322)$ of all wasps reared, followed by D. blackburni $(21 \%), \quad P$. hawaiiensis $(21 \%)$, and C. grapholithae $(7 \%)$. There was no distinct relationship between overall parasitism and elevation.

Scotorythra larvae (all Geometridae collected were known or assumed to be Scotorythra spp.) collected from Sophora foliage were parasitized by wasps, Hyposoter exiguae (Viereck), D. blackburni (Cameron) [Ichneumonidae]; Meteorus laphygmae Viereck (Braconidae); and the fly, Chaetogaedia monticola (Bigot) [Tachinidae]. All except M. laphygmae also parasitized Peridroma larvae. H. exiguae was most frequently reared from both moth species, accounting for $62 \%(36 / 58)$ of the parasitism. The incidence of parasitism of Scotorythra larvae by all species was $28 \%$ $(48 / 174)$ and it declined marginally from $33 \%(2 / 6)$ at 2200 $\mathrm{m}$ elevation to $24 \%(9 / 38)$ at $2800 \mathrm{~m}\left(R^{2}=0.62, F=4.9\right.$, $P=0.11)$ when data for western and northern slopes were pooled.

\section{Predatory wasps and ants}

Vespula pensylvanica were distributed widely on Mauna Kea but generally were trapped less frequently and in lower numbers on the western slope. Individuals were trapped throughout the year, low numbers infrequently during January-April and greater numbers almost continually during July-November. Queens were trapped during January-September but with a strong peak during May-June (2000). There was no relationship between Vespula numbers and elevation during the 4 years of surveys (Fig. 11).

Four species of ants were found on surveys below Loxioides habitat on the south-western slope of Mauna Kea (Table 4). Two species, Cardiocondyla venustula Wheeler and Linepithema humilis (Mayr) [Argentine ant], ranged into Loxioides habitat, and their distributions (number of 


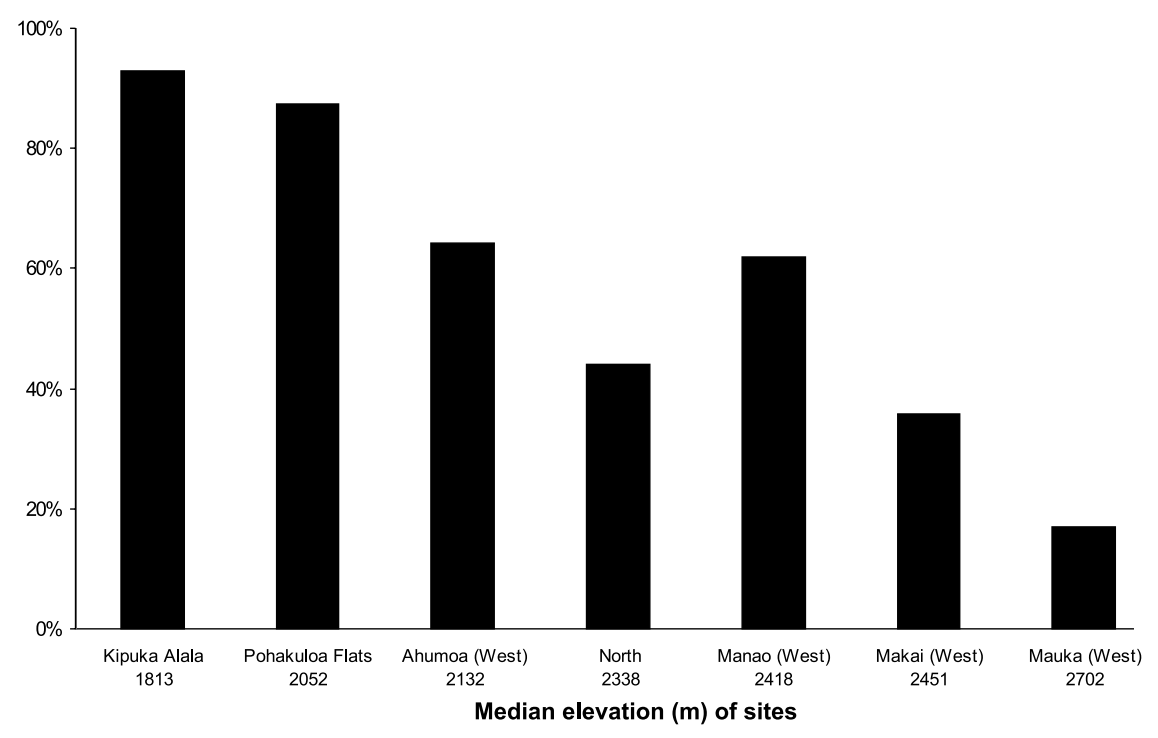

Figure 10 Incidence of parasitism of Cydia spp. larvae by endoparasitic wasps at seven sites in 1997. Elevation influenced parasitism rates at four sites (Ahumoa, Manao, Makai, Mauka) on the western slope of Mauna Kea, where Loxioides nesting and foraging were most concentrated. On the northern slope, where sampling was conducted continuously along an elevation gradient, the overall rate of parasitism was intermediate and consistent with rates on the western slope. Few larvae escaped parasitism at the lowest elevation sites on Mauna Kea (Pōhakuloa Flats) and Mauna Loa (Kīpuka 'Alalā).

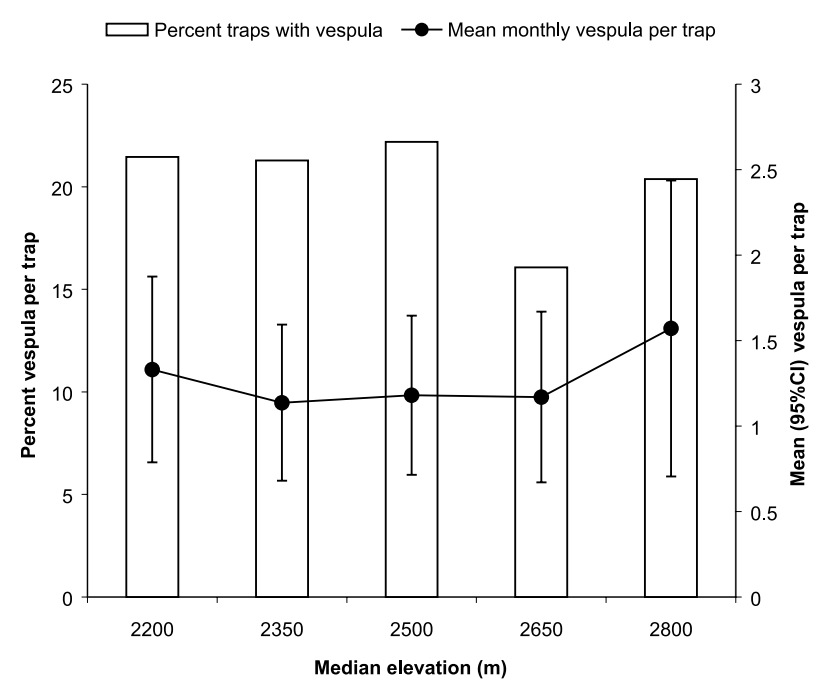

Figure II Prevalence of Vespula pensylvanica (Saussure) (Vespidae), or Western yellowjacket on the western and northern slopes of Mauna Kea during June 1998-February 2002. Monthly capture rates were relatively low and unaffected by elevation.

Table 4 Species of ants (Formicidae) and maximum elevations where they were detected on the south-western slope of Mauna Kea during 1999-2000

\begin{tabular}{ll}
\hline Species & $\begin{array}{l}\text { Maximum } \\
\text { elevation (m) }\end{array}$ \\
\hline Cardiocondyla venustula Wheeler & 2450 \\
Linepithema humilis (Mayr) [Argentine ant] & 2300 \\
Pheidole megacephala (Fabricius) [Big-headed ant] & 2050 \\
Monomorium pharaonis (Linnaeus) [Pharaoh ant] & 1900 \\
\hline
\end{tabular}

bait stations where they were detected) increased by factors of 4.4 (Cardiocondyla) and 1.6 (Linepithema) from 1999 to 2000. Cardiocondyla were mostly distributed just above a concentration of Linepithema extending $>8 \mathrm{~km}^{2}$. Ant distributions almost never overlapped, and the two species occurred at the same station on only six occassions.

\section{Distribution of weeds}

We found five alien grass species with potential to change the fire regime or suppress native plant regeneration within Loxioides habitat on the western slope of Mauna Kea: Anthoxanthum odoratum L. (sweet vernal grass), Dactylis glomerata L. (orchard grass), Holcus lanatus L. (common velvet grass), Pennisetum setaceum, Chiov., P. clandestinum Chiov. (Kikuyu grass), and Poa pratensis L. (Kentucky blue grass). Percentage cover of alien grasses was highest at mid elevation (Table 5). P. setaceum, a grass species of special concern because of its propensity to generate grass/fire cycles, was represented by small, isolated populations in the study area. However, it was abundant and widespread in shrubland below the forest occupied by Loxioides (Fig. 12).

Delairea odorata, an invasive vine capable of dominating forest canopy, was mostly confined to a large area at low and mid elevation (Fig. 12). However, we found scattered patches as high as $2594 \mathrm{~m}$ elevation.

\section{Distribution of introduced small mammals}

Mus musculus was widespread and abundant throughout the western slope of Mauna Kea but were most frequently caught at low elevations (Table 6). Pooled Mus capture rates averaged 11.3/100 trap-nights \pm 0.5 (SE) and increased by a factor of 1.8-1.9 during each successive survey (5.0/100 t-n; 9.2/100 t-n; 17.3/100 t-n). Rattus rattus were rarely caught 
Table 5 Percent cover of alien and grass species in three elevation strata on the western slope of Mauna Kea

\begin{tabular}{lllc}
\hline Elevation strata & Vegetation plots & Percent cover of alien grass species (mean \pm SE) & Percent cover of native grass species (mean \pm SE) \\
\hline Low $(2028-2297 \mathrm{~m})$ & 67 & $10.35 \pm 1.20$ & $1.61 \pm 0.82$ \\
Mid $(2303-2540 \mathrm{~m})$ & 93 & $14.04 \pm 1.30$ & $5.98 \pm 0.84$ \\
High $(2559-2814 \mathrm{~m})$ & 71 & $11.22 \pm 1.07$ & $9.38 \pm 1.24$ \\
\hline
\end{tabular}

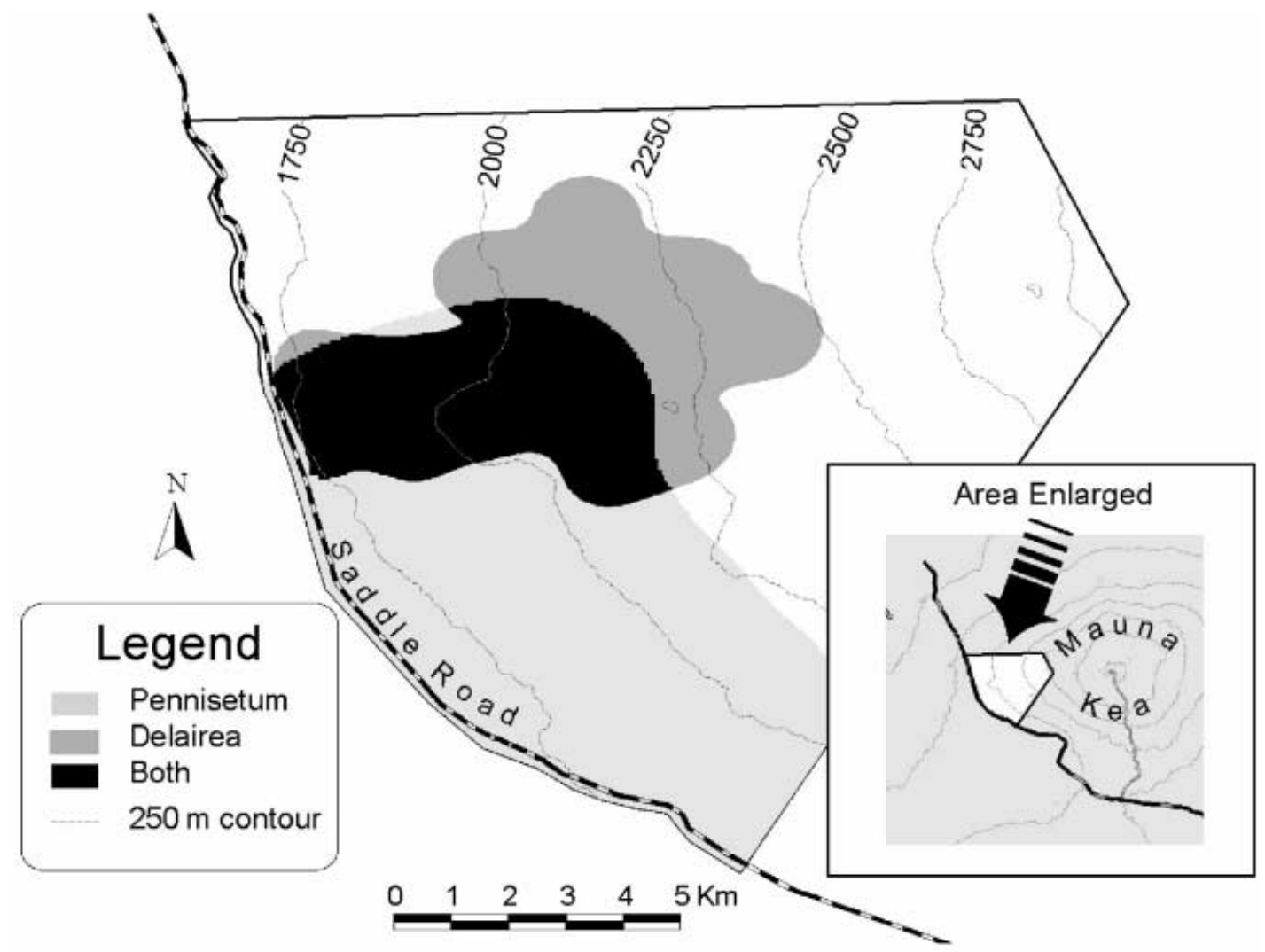

Figure 12 Invasive weeds of special concern in Loxioides habitat include Pennisetum setaceum Chiov. (Poaceae; fountain grass), a firepromoting species of grass, and Delairea odorata Otto ex Walp. (Asteraceae; Cape ivy), a vine that dominates tree canopies. Both species occurred primarily at low and mid elevations but, like many other weeds introduced from Mediterranean or temperate areas, are likely to spread throughout subalpine forest on Mauna Kea.

and then only at low and mid elevations in forests dominated by Myoporum.

Felis catus and H. auropunctatus were captured throughout both study areas on the western and northern slopes of Mauna Kea. However, both species were trapped somewhat more often on the western slope and less frequently at lower elevations in both study areas (Table 7).

\section{DISCUSSION}

\section{Resources available to Loxioides along an elevation gradient}

Our results demonstrate that elevation strongly influenced the timing and magnitude of Sophora flower and seed production (also see Fancy et al., 1993; Hess et al., 2001).
Along a 786-m gradient of elevation, seeds were produced throughout the year, although sometimes at low levels. Seeds were abundantly available over the whole range of elevation for about $69 \%$ more time than in areas of only one-third the range of elevation.

Rainfall seems unlikely to have influenced Sophora phenology on the western slope of Mauna Kea, given that rainfall is not consistently related to elevation in this region (Juvik et al., 1993). Furthermore, Sophora phenology seems not to vary obviously along a rainfall gradient where elevation is relatively constant (USGS, Unpubl. data). Although we do not understand the physiological factors governing the timing of Sophora reproduction, additional analyses may help explain the potential effects on Sophora phenology of other ecological factors (e.g. habitat heterogeneity, annual rainfall variation) 
Table 6 Capture rates (individuals per trap-night) of rodents, Mus musculus Linnaeus and Rattus rattus Linnaeus, in three strata of elevation on the western slope of Mauna Kea. Results were pooled for three surveys: June 2000, January 2001, and June 2001). Elevation strata extended 385-399 m: Low (1785-2180 m), Mid (2180-2579 m), High (2596-2981 m). Rat traps were included in the calculation of $M u s$ trap-nights because $M u s$ were often caught in rat traps. Mean \pm SE calculated from capture rates per station (multiple traps)

\begin{tabular}{|c|c|c|c|}
\hline & Low & Mid & High \\
\hline \multicolumn{4}{|l|}{ Mus } \\
\hline Rate & $15.7 \pm 1.0$ & $\begin{array}{lll}10.4 & 0.8\end{array}$ & $9.2 \pm 0.9$ \\
\hline Animals & 393 & 508 & 284 \\
\hline Trap-nights & 2520 & 4896 & 3096 \\
\hline \multicolumn{4}{|l|}{ Rattus } \\
\hline Rate & $0.2 \pm 0.2$ & $0.2 \pm 0.1$ & 0 \\
\hline Animals & 2 & 3 & 0 \\
\hline Trap-nights & 840 & 1632 & 1032 \\
\hline
\end{tabular}

and physical characteristics (e.g. tree size and vigour). Further study may also reveal why high-elevation trees tend to produce larger flower and pod crops and why the reproductive output of low-elevation trees is so variable.

In contrast to Sophora, we detected no phenological response to elevation by Myoporum, albeit over a reduced range of elevation. Myoporum flowering patterns were weakly seasonal at best, resulting in remarkably stable, high levels of fruit throughout the year. Although Loxioides eat Myoporum fruit, they do not seem particularly attracted to it (USGS, Unpubl. data).

Loxioides are concentrated on the western slope of Mauna Kea largely because of the sustained production of food there by Sophora trees. In contrast, populations are small and declining where habitats have contracted in elevation (Scott et al., 1984; Jacobi et al., 1996). Sophora pod availability at different elevations may affect Loxioides home range size (Fancy et al., 1993). In addition, Loxioides track pods, but not flowers, as they appear seasonally at different elevations, although they do not travel far around the slopes of Mauna Kea in search of food (van Riper et al., 1978; Hess et al., 2001). Flower and pod phenology vary substantially among trees within a narrow range of elevation. Therefore, food is available longer than if trees were more synchronous. Food should also be available for the longest time and in greatest abundance where tree density and canopy cover are highest. Canopy cover is relatively dense on the western slope, thus food resources are produced in larger quantities per unit of area (Scott et al., 1984; USGS, Unpubl. data). In addition, Loxioides prefer to forage and nest in larger trees (van Riper, 1980a; Pletschet \& Kelly, $1990)$, which are relatively common on the western slope (Scott et al., 1984; USGS, Unpubl. data).

The availability of Sophora pods strongly affects the timing and intensity of Loxioides nesting (van Riper, 1980a; Pratt et al., 1997; Banko et al., in press a), and nest success decreases later in the breeding season when pods are less abundant (Pletschet \& Kelly, 1990). Although Sophora seeds are the major food of nestlings, moth larvae found in Sophora pods (Cydia) or on Sophora foliage (Scotorythra) are frequently fed to nestlings and fledglings and are an important prey of Loxioides throughout the year (Banko et al., in press a). The availability of Cydia larvae depends on pod abundance; however, when pods are abundant, the incidence of Cydia per pod is low (Brenner et al., in press), potentially increasing the time that Loxioides search for these prey. Therefore, the role of insect availability in regulating Loxioides reproductive behaviour is difficult to separate from pod availability. Nevertheless, insect prey may be critically important to Loxioides demography (see Poulin et al., 1992).

\section{Threats to Loxioides food resources}

Availability of Cydia and other moth larvae was affected by parasitism and perhaps predation by alien insects. Cydia and Scotorythra were parasitized by six wasp and one fly species. All these endoparasitoid species are alien except perhaps one wasp, Euderus metallicus; at least one wasp, M. laphygmae, and the fly, C. monticola, were introduced as biological control agents. Although temporal and spatial patterns of

Table 7 Capture rates (animals/100 trap-nights) for Felis catus Linnaeus and Herpestes auropunctatus Hodgson at two sites on Mauna Kea and at three strata of elevation (both sites combined). Elevation strata extended 385-399 m: Low (1785-2180 m), Mid (2180-2579 m), High (2596-2981 m). Trapping occurred over 1244 trap-nights (t-n): West Forest Transects [28 July-20 August 1998 (329 t-n); 16 June-15 July 1999 (170 t-n); 19 September-29 September 2000 (289 t-n)]; North Forest Transects [30 April-29 May 1998 (199 t-n); 10 September-23 September 1998 (257 t-n)]. Mean \pm SE calculated from capture rates per station (single trap)

\begin{tabular}{|c|c|c|c|c|c|}
\hline & \multicolumn{2}{|c|}{ Study sites (strata combined) } & \multicolumn{3}{|c|}{ Elevation strata (sites combined) } \\
\hline & West & North & Low & Mid & High \\
\hline \multicolumn{6}{|l|}{ Felis } \\
\hline Rate & $4.8 \pm 0.9$ & $3.9 \pm 0.9$ & $3.7 \pm 1.3$ & $4.2 \pm 0.8$ & $7.0 \pm 2.3$ \\
\hline Animals & 36 & 21 & 8 & 35 & 14 \\
\hline \multicolumn{6}{|l|}{ Herpestes } \\
\hline Rate & $2.1 \pm 0.9$ & $1.0 \pm 0.5$ & $0.9 \pm 0.7$ & $2.1 \pm 0.8$ & $1.2 \pm 0.9$ \\
\hline Animals & 22 & 6 & 2 & 23 & 3 \\
\hline Total trap-nights & 788 & 456 & 202 & 831 & 211 \\
\hline
\end{tabular}


parasitism by particular species may have varied, overall parasitism rates tended to decrease as elevation increased and moth larvae were more abundant at higher elevations. Although Loxioides encounter their preferred insect prey more frequently at higher elevations, they may track Cydia larvae as well as Sophora pods as the availability of both change over time along the elevation gradient. Reduced parasitoid impacts at higher elevations may also partially explain why Loxioides nest at about twice the density in Sophora-dominated forest above $2440 \mathrm{~m}$ as they do in mixed Myoporum-Sophora forest (USGS, unpubl. data). Another native moth species, Uresephita polygonalis virescens (Butler) [Crambidae] was noted as an important prey of Loxioides historically (Perkins, 1903), but it is no longer observed in their diet on Mauna Kea, where it is rare perhaps in part due to parasitism.

Vespula prevalence was not related to elevation. Relatively low capture rates suggest that populations may still be colonizing the western slope of Mauna Kea or that habitat conditions are less favourable there. In either case, scattered populations of Vespula probably have little impact on native insects that are preyed upon by Loxioides and other native birds or on insects that pollinate native plants. However, larger, more concentrated populations of Vespula pose serious threats to native insects (Gambino et al., 1990; Gambino, 1992). Some colonies over-winter as high as 2600 m elevation on Haleakalā, Maui (L. Loope, USGS, Pers. comm.), and it seems that Vespula populations are adapting to conditions on Mauna Kea, as we have caught workers and discovered a nest during winter above $2200 \mathrm{~m}$.

Ants are just beginning to invade habitat currently occupied by Loxioides, although their abundance in at least portions of the former range may hinder Loxioides restoration. Linepithema poses the greatest potential threat to insect prey of Loxioides because it is a voracious insect predator (Cole et al., 1992), can spread rapidly in dry upland areas (Krushelnycky \& Reimer, 1996), and is the most abundant and widespread ant species near Loxioides habitat. Although discovered at $2500 \mathrm{~m}$ elevation in Loxioides habitat in 1992 (Wetterer et al., 1998), we have not subsequently found Linepithema at these sites or anywhere above $2300 \mathrm{~m}$ on Mauna Kea. Nevertheless, Linepithema occurs at $2880 \mathrm{~m}$ elevation on Haleakalā, Maui (Cole et al., 1992); therefore, it seems likely that it will colonize most of the dry forest on Mauna Kea. Colonies consisting of multiple queens and multiple connected nests produce many eggs and are sustained by consuming many prey. Although Cardiocondyla has generally been regarded as a low-impact, lowdensity species in Hawai'i (Krushelnycky \& Reimer, 1996), it should be closely monitored because it already occurs within Loxioides habitat and disperses with winged queens. Furthermore, our surveys indicate that populations are able to increase rapidly over a relatively large area.

Other ant species on Mauna Kea are of less concern with respect to Loxioides conservation. Pheidole megacephala (Fabricius) [big-headed ant] is limited by elevation. Although the Mauna Kea population occurs at the highest elevation reported in Hawai'i, it is below the current range of Loxioides and seems unlikely to spread higher. Monomorium pharaonis (Linnaeus) [Pharaoh ant] was found at a small number of low-elevation sites and would seem to be even less threatening to Loxioides higher on the mountain.

\section{Threats to Loxioides habitat from invasive weeds}

At least five problematic alien species of grass have invaded Loxioides habitat, aided in their spread by large populations of feral ungulates that disturbed the soil and preferentially browsed native species (Scowcroft \& Conrad, 1992; Stone et al., 1992). Individually or collectively, these grass species escalate fire threats and may suppress regeneration of native plants. Many alien grasses regenerate and spread rapidly following fire or other disturbance, which can lead to grass/fire cycles that promote increased grass cover and fuel loading, changes in native plant community structure and composition, and invasions of additional weeds (Hughes et al., 1991; D'Antonio and Vitousek, 1992; Smith and Tunison, 1992). Therefore, fire-prone alien grasses that form dense, continuous fuel beds could transform the subalpine forests of Mauna Kea to alien-dominated woodland or grassland by grass/fire cycles. Even without fire, invasive grasses may reduce growth and recruitment of native species, including Sophora (Hughes and Vitousek, 1993; Williams, 1994; D’Antonio et al., 1998, 2000; Hess et al., 1999; Cabin et al., 2000), and alter ecosystem processes (Mueller-Dombois, 1973; Asner and Beatty, 1996; Ley and D'Antonio, 1998).

Alien grasses threaten Sophora forests more at mid elevations, where their cover is most dense, but invasive species could increase at higher elevations if grass/fire cycles develop at lower elevations. Of all species, $P$. setaceum poses the greatest fire threat to Loxioides habitat. Its extensive distribution in shrubland below the forest on the southwestern slope and scattered occurrence in Loxioides habitat make real the prospect of catastrophic grass/fire cycles.

Delairea odorata vines climb over Sophora trees and other vegetation in dense tangles that obscure light and weigh heavily on branches. We have observed Delairea vines covering individual trees for over 10 years without killing them; however, vigor and production of flowers and pods seem reduced, probably because of reduced light levels. Delairea probably also suppresses seedlings of Sophora and other native species. Although concentrated at low and mid elevations on the western slope of Mauna Kea, distant satellite populations demonstrate that Delairea is spreading upslope. Many other weeds that are native to Mediterranean or temperate areas thrive in upland Mauna Kea, including Ulex europaeus L. (gorse), which has spread to over $2400 \mathrm{~m}$ elevation from a large infestation in pastures on the southeastern flank of Mauna Kea (Cuddihy \& Stone, 1990; Juvik et al., 1992). Ulex will likely change the fire regime and displace Sophora and other native plants from large areas of subalpine forest if allowed to spread much farther upslope.

\section{Threats to Loxioides from small mammalian predators}

Of the four species of introduced small mammals occurring on Mauna Kea, only Mus is not known to prey on Loxioides 
adults, nestlings, or eggs; however, Mus forage in trees at night and may disturb birds at their nests or roosts (Banko et al., in press a). Because Mus are ubiquitous in Loxioides habitat, their impacts on birds and the dry forest ecosystem are important to understand. Although Felis and Herpestes prey upon Mus on Mauna Kea (Amarasekare, 1994; USGS, Unpubl. data), our trapping results suggest that these predators were not more active at elevations where $M u s$ were most abundant. Therefore, the importance of rodents in sustaining introduced carnivores warrants further study. Rattus is rare in Loxioides habitat, especially at higher elevations in forest dominated by Sophora (Amarasekare, 1993, 1994; this study), yet it occasionally depredates nests (Pletschet \& Kelly, 1990; Pratt et al., 1997) and its impact on birds seems out of proportion to its numbers. Felis, on the other hand, is the most serious predator of Loxioides, particularly at nests (van Riper, 1980a; Pratt et al., 1997; Banko et al., in press a), and it should be removed from native bird habitat. Herpestes tends to be less common than Felis at higher elevations, but they apparently seldom climb trees and rarely depredate Loxioides nests (Banko et al., in press a). Overall, Loxioides find little relief from introduced predators anywhere in their range. Nevertheless, predators probably have disproportionately large impacts on bird populations that are isolated in scattered habitat remnants, such as those found on the eastern slope of Mauna Kea.

\section{Response of Loxioides to forest dynamics along the elevation gradient}

The subalpine forest of Mauna Kea is relatively simple in composition and structure, being dominated by only two species of trees and some species of shrubs. Nevertheless, the forest will likely become further dominated by Sophora even at lower elevations, where long-term, intense browsing on Sophora by feral ungulates may have biased composition in favour of less palatable Myoporum (van Riper, 1980b; Scowcroft \& Giffin, 1983; Hess et al., 1999). Sophora regeneration greatly exceeds Myoporum at all elevations on the western slope, although Myoporum trees are more abundant at lower elevations (Hess et al., 1999; USGS, Unpubl. data).

As Sophora increases, vegetation dynamics and avian habitat use patterns will become even more simplified. Loxioides may soon begin to benefit from the large cohort of Sophora that has sprouted following reductions of feral ungulate populations, having in the meantime largely ignored Sophora saplings as foraging and nesting substrates (USGS, Unpubl. data). Where Sophora is dominant, Loxioides tend to nest and forage primarily in larger trees (USGS, Unpubl. data), but they utilize habitat along the entire gradient of elevation because Sophora-based resources are sufficiently available throughout. Although Myoporum fruit is frequently eaten by Loxioides and is available at mid and lower elevations throughout the year, birds are probably attracted to lower elevations more by the changing availability of Sophora seeds than by the nearly constant availability of Myoporum fruit. When, for example, Loxioides occur in forest dominated by Myoporum, they spend more time foraging in Sophora (USGS, Unpubl. data). Therefore, as Sophora increases in relative abundance throughout the lower portion of the western slope, we predict that Loxioides will respond even more noticeably to the availability of its resources along the elevation gradient.

A challenge yet to be met is understanding how elevation affects the structure and dynamics of the dry subalpine forest, given the level of disturbance by feral browsers and the robust response of Sophora and other native plants to their reduction in numbers. For example, vegetation and habitat characteristics - not elevation - undoubtedly influence the abundance of Mus and Rattus (Amarasekare, 1994) as well as many weed species, but we are less certain about relationships between alien insects and habitat. We anticipate that alien grasses and other species will decline if forest recovery continues, but some weeds and pests will undoubtedly require long-term control. Management strategies, however, should anticipate and minimize compensatory increases of one alien threat because of the control of another.

Loxioides have been stranded in the uppermost portion of their historic range; hence, the gradient of elevation still available to them is paramount to their survival (Scott et al., 1984). The range of elevation on the western slope of Mauna Kea promotes year-round availability of food resources and dampens impacts of some alien threats that would otherwise be more concentrated. Conservation should focus on controlling alien threats and restoring native forests at lower elevation to extend the gradient of elevation around Mauna Kea. For example, Loxioides have been absent for decades from the northern slope of Mauna Kea, where the gradient of elevation is shorter and forest is more fragmented than on the western slope (Scott et al., 1984; USGS, Unpubl. data). Loxioides may be re-established on the northern slope when pastures below Mauna Kea Forest Reserve are rehabilitated, thus restoring the elevation gradient. Where habitat width cannot be expanded, Loxioides must rely on alternative resources when Sophora flowers and pods become scarce. Loxioides forage on other plant species even in areas dominated by Sophora; therefore, fostering natural tree and shrub diversity should enhance foraging opportunities. At the same time, habitat patches in fragmented forests should be expanded to the limits of the available range of elevation and Sophora canopy cover should be promoted by controlling feral ungulates, fire, invasive weeds, and other threats. It may be less feasible to curtail some disturbance factors impeding Loxioides recovery (e.g. military training within Pōhakuloa Flats on the southern slope of Mauna Kea).

\section{Response of other Hawaiian birds to elevation and other environmental gradients}

In historic times, Hawaiian forest birds have become increasingly restricted to higher portions of their former range (Banko et al., 2001), and elevation significantly influences the distribution and abundance of most $(73 \%)$ 
native species (Scott et al., 1986). In addition to Loxioides, other species that track resources along elevation gradients include nectarivores that rely on Metrosideros polymorpha Banks ex Gaertn. (Myrtaceae; 'ōhi'ā). Several Hawaiian honeycreepers that follow Metrosideros flowering are Himatione sanguinea (Gmelin) ['apapane], Vestiaria coccinea (Forster) ['i'iwi], and Hemignathus virens (Gmelin) [Hawai'i 'amakihi] (Baldwin, 1953; van Riper, 1984; Carothers, 1986; Ralph \& Fancy, 1994, 1995; Berlin et al., 2000, 2001). Other native birds, such as Moho nobilis (Merrem) [Hawai'i 'ó'̄o] and other extinct members of the Meliphagidae, may also have tracked Metrosideros in addition to other sources of nectar (Perkins, 1903, pp. 441-443). The availability of Sophora nectar affects the movements of some bird species, attracting Himatione and Vestiaria, for example, to the western slope of Mauna Kea from wet forest habitat on the eastern slope (Hess et al., 2001). Although no seasonal movements of insectivores have been recorded, specialized frugivores and granivores may once have moved in response to fruit availability when forests were less fragmented. For example, the now-extinct Rhodacanthis palmeri Rothschild (hōpue or greater koafinch) specialized on the immature seeds of Acacia koa A. Gray (Fabaceae), or koa (Perkins, 1903, pp. 437). The timing of Acacia seed production may be influenced by elevation (Lamoureux et al., 1981), but studies to confirm this are needed. Psittirostra psittacea (Gmelin) [Drepanidinae; ' $\overline{\mathrm{o}} \overline{\mathrm{u}}$ ] and Corvus hawaiiensis Peale [Corvidae; 'alalā], relied heavily on the flowers and fruit of Freycinetia arborea Gaud. [Pandanaceae; 'ie‘ie] when these thick vines cloaked large tracts of low- and mid-elevation forest. The phenology of Freycinetia is undocumented with regard to elevation, but both Corvus and Psittirostra moved in and out of the broad Freycinetia zone according to seasonal food availability (Perkins, 1903, pp. 372, 389, 433). In contrast, the Myoporum specialist, Chloridops kona Wilson (Drepanidinae; Kona grosbeak; Perkins, 1903, p. 439), may not have moved frequently or far in search of fruit, judging from the negligible response of Myoporum to elevation and the abundance of its fruit throughout the year on Mauna Kea. Nevertheless, historic changes in native vegetation at low and mid elevations would have disrupted foraging patterns of birds that did track the seasonal availability of foods across the landscape, and their populations probably declined unless they were able to switch to alternative foods. Besides challenges to efficient foraging, species that continue to track resources below about $1500 \mathrm{~m}$ elevation today are more likely to be exposed to mosquitoes infected with avian malaria and pox (Warner, 1968; van Riper et al., 1986).

\section{Conservation on islands}

Many factors may endanger populations, but it is difficult to identify the most important variables when their influences intertwine or overlap, when their effects are complex or indirect, or when they act over different temporal and spatial scales. Even on remote islands, where the limited number of species interactions may give the perception (perhaps more often an illusion) of ecological simplicity, biologists should not be tempted to assume that only one or two factors are forcing a species towards extinction. Thus, we must examine a wide spectrum of possible factors to begin to understand how to protect native species, and that is our approach to developing conservation strategies for Loxioides and other Hawaiian birds.

In remote oceanic islands, habitat is limited in area and species diversity is relatively low, although endemism is high. Human impacts are most severe at low elevations, and species confined only to lowland habitats are usually extirpated first. Species that range into higher elevations may escape extinction initially but, becoming stranded in marginal habitat, they eventually disappear. Such is the case for most Hawaiian forest birds. At least half of all endemic land birds were extirpated when humans colonized the islands (Olson \& James, 1991; James \& Olson, 1991), and most of the remainder are threatened with extinction in the short term (Banko et al., 2001). Nearly all remaining species survive only in the uppermost portion of their former ranges, for the most part above the limits of introduced diseasebearing mosquitoes and where feral ungulates and other invasive species have not yet degraded habitats beyond tolerable limits. Extinctions of birds on other Pacific islands have been at least as massive as in Hawai'i (Steadman, 1995). Conserving birds and other organisms along gradients of elevation and other dimensions of habitat therefore takes on special relevance and urgency in Hawai'i and other oceanic islands. Just as early Hawaiians controlled resources in wedges of land (ahupua'a) typically extending from the coast to the upper slopes of the volcanoes, ecosystem conservation also must include a vertical dimension that sufficiently encompasses the distribution and movement of species and processes up and down mountain slopes.

\section{ACKNOWLEDGMENTS}

We thank A. Agness, G. Brenner, D. Cerasale, L. Gold, E. Gray, S. Hess, M. Kweskin, L. Laniawe, J. Leialoha, S. Marshall, L. Miller, B. Muffler, C. Murray, K. Radasky, T. Rogers, R. Rounds, J. Semones, H. Weddle, M. Wiley for assistance in the field, laboratory, and office. J. Jacobi provided support and encouragement during the early portion of work on Mauna Kea. We are grateful to Hawai'i Division of Forestry and Wildlife for permission to work on Mauna Kea. We thank US Army Garrison, Hawai'i for permission to work at Kīpuka 'Alalā and Pōhakuloa Flats. Funding was provided by US Army Garrison, Hawai'i and USGS-Pacific Island Ecosystem Research Center.

\section{REFERENCES}

Amarasekare, P. (1993) Potential impact of mammalian nest predators on endemic honeycreepers of western Mauna Kea, Hawaii. Conservation Biology, 7, 1-9.

Amarasekare, P. (1994) Ecology of introduced small mammals on western Mauna Kea, Hawaii. Journal of Mammalogy, 75, 24-38. 
Asner, G.P. \& Beatty, S.W. (1996) Effect of an African grass invasion on Hawaiian shrubland nitrogen biogeochemistry. Plant and Soil, 186, 205-211.

Atkinson, I.A.E. (1977) A reassessment of factors, particularly Rattus rattus $\mathrm{L}$., that influenced the decline of endemic forest birds in the Hawaiian Islands. Pacific Science, 31, 109-133.

Baldwin, P.H. (1953) Annual cycle, environment, and evolution in the Hawaiian honeycreepers (Aves: Drepanididae). University of California Publications in Zoölogy, 52, 285398.

Banko, W.E. (1979) History of endemic Hawaiian bird specimens in museum collections. CPSU/UH Avian History Report. 2. Cooperative National Park Resources Studies Unit, University of Hawai'i at Mānoa, Honolulu, HI, USA.

Banko, P.C., David, R.E., Jacobi, J.D. \& Banko, W.E. (2001) Conservation status and recovery strategies for endemic Hawaiian birds. Studies in Avian Biology, 22, 359-376.

Banko, P.C., Johnson, L., Lindsey, G.D., Fancy, S.G., Pratt, T.K., Jacobi, J.D. \& Banko, W.E. (in press a) Palila (Loxioides Bailleui). The Birds of North America (eds A. Poole and F. Gill). The Birds of North America, Inc., Philadelphia, PA, USA.

Banko, P.C., Cipollini, M.L., Breton, G.W., Paulk, E., Wink, M. \& Izhaki, I. (2002) Seed chemistry of Sophora chrysophylla (mamane) in relation to the diet of the specialist seed predator Loxioides bailleui (palila) in Hawaii. Journal of Chemical Ecology, 28, 1389-1406.

Beauvais, G.P. \& Buskirk, S.W. (1996) Modifying estimates of sampling effort to account for sprung traps. Journal of Mammalogy, 77, 205-219.

Berlin, K.E., Pratt, T.K., Simon, J.C., Kowalsky, J.R. \& Hatfield, J.S. (2000) Plant phenology in a cloud forest on the Island of Maui, Hawaii. Biotropica, 32, 90-99.

Berlin, K.E., Simon, J.C., Pratt, T.K., Kowalsky, J.R. \& Hatfield, J.S. (2001) 'Âkohekohe response to flower availability: seasonal abundance, foraging, breeding, and molt. Studies in Avian Biology, 22, 202-212.

Brenner, G.J., Oboyski, P.T. \& Banko, P.C. (2002) Parasitism of. Cydia spp. (Lepidoptera: Tortricidae) on Sophora chrysophylla (Fabaceae) along an elevation gradient of dry subalpine forest on Mauna Kea, Hawaii. Pan-Pacific Entomologist, 78.

Bryan, L.W. (1947) Twenty-five years of forestry work on the Island of Hawaii. The Hawaiian Planters' Record, 51, 1-80.

Cabin, R.J., Weller, S.G., Lorence, D.H., Flynn, T.W., Sakai, A.K., Sandquist, D. \& Hadway, L.J. (2000) Effects of longterm ungulate exclusion and recent alien species control on the preservation and restoration of a Hawaiian tropical dry forest. Conservation Biology, 14, 439-453.

Carothers, J.H. (1986) Behavioral and ecological correlates of interference competition among some Hawaiian Drepanidinae. Auk, 103, 564-574.

Cole, F.R., Medeiros, A.C., Loope, L.L. \& Zuehlke, W.W. (1992) Effects of the Argentine ant on arthropod fauna of the Hawaiian high-elevation shrubland. Ecology, 73, 13131322.

Cuddihy, L.W. \& Stone, C.P. (1990) Alteration of native Hawaiian vegetation: effects of humans, their activities and their introductions. University of Hawai'i Press, Honolulu, HI, USA.
D’Antonio, C.M., Hughes, R.F., Mack, M., Hitchcock, D. \& Vitousek, P.M. (1998) The response of native species to removal of invasive exotic grasses in a seasonally-dry Hawaiian woodland. Journal of Vegetation Science, 9, 699712.

D’Antonio, C.M., Tunison, J.T. \& Loh, R.K. (2000) Variation in the impact of exotic grasses on native plant composition in relation to fire across an elevation gradient in Hawaii. Austral Biology, 25, 507-522.

D’Antonio, C.M. \& Vitousek, P.M. (1992) Biological invasions by exotic grasses, the grass/fire cycle, and global change. Annual Review of Ecology and Systematics, 23, 63-87.

Davis, H.G., Eddy, G.W., McGovern, T.P. \& Beroza, M. (1969) Heptyl butyrate, a new synthetic attractant for yellow jackets. Journal of Economic Entomology, 62, 1245.

Dougill, S.J., Banko, P.C. \& Gold, L.S. (in review) Monitoring the distribution of alien plants to facilitate recovery of a dry, subalpine Hawaiian forest. Natural Areas Journal,.

Fancy, S.G., Sugihara, R.T., Jeffrey, J.J. \& Jacobi, J.D. (1993) Site tenacity of the endangered palila. Wilson Bulletin, 105, 587-596.

Finch, D.M. (1991) Positive associations among riparian bird species correspond to elevational changes in plant communities. Canadian Journal of Zoology, 69, 951-963.

Freed, L.A., Conant, S. \& Fleischer, R.C. (1987) Evolutionary ecology and radiation of Hawaiian passerine birds. Trends in Ecology and Evolution, 2, 196-203.

Gagné, W.C. \& Cuddihy, L.W. (1999) Vegetation. Manual of the flowering Plants of Hawai'i, Vol. 1 rev edn (eds W.L. Wagner, D.R. Herbst and S.H. Sohmer), pp. 45-114. Bishop Museum Special Publication 97, University of Hawai'i Press and. Bishop Museum Press, Honolulu, HI, USA.

Gambino, P. (1992) Yellowjacket (Vespula pensylvanica) predation at Hawaii Volcanoes and Haleakala National Parks: identity of prey items. Proceedings of the Hawaiian Entomological Society, 31, 157-164.

Gambino, P., Medeiros, A.C. \& Loope, L.L. (1990) Invasion and colonization of upper elevations on East Maui (Hawaii) by Vespula pensylvanica (Hymenoptera: Vespidae). Annals of the Entomological Society of America, 83, 1088-1095.

Goff, M.L. \& van Riper, C. III (1980) Distribution of mosquitoes (Diptera: Culicidae) on the east flank of Mauna Loa Volcano, Hawaii. Pacific Insects, 22, 178-188.

Hess, S.C., Banko, P.C., Brenner, G.J. \& Jacobi, J.D. (1999) Factors related to the recovery of subalpine woodland on Mauna Kea, Hawaii. Biotropica, 31, 212-219.

Hess, S.C., Banko, P.C., Reynolds, M.H., Brenner, G.J., Laniawe, L.P. \& Jacobi, J.D. (2001) Drepandidine movements in relation to food availability in subalpine woodland on Mauna Kea, Hawai'i. Studies in Avian Biology, 22, 154-163.

Hughes, R.F. \& Vitousek, P.M. (1993) Barriers to shrub reestablishment following fire in the seasonal submontane zone in Hawaii. Oecologia, 93, 557-563.

Hughes, R.F., Vitousek, P.M. \& Tunison, T. (1991) Alien grass invasion and fire in the seasonal submontane zone in Hawaii. Ecology, 72, 743-746.

Jacobi, J.D., Fancy, S.G., Giffin, J.G. \& Scott, J.M. (1996) Long-term population variability in the palila, an endangered Hawaiian honeycreeper. Pacific Science, 50, 363-370. 
James, H.F. \& Olson, S.L. (1991) Descriptions of thirty-two new species of birds from the Hawaiian Islands: Part II. Passeriformes. Ornithological Monographs, 46, 1-88.

Juvik, J.O. \& Juvik, S.P. (1984) Mauna Kea and the myth of multiple use. Mountain Research and Development, 4, 191-202.

Juvik, J.O., Juvik, S.P. \& Hamilton, L.S. (1992) Altitudinal resource zonation versus control: land use conflict on two Hawaiian mountains. Mountain Research and Development, 12, 211-226.

Juvik, J.O., Nullet, D., Banko, P.C. \& Hughes, K. (1993) Forest climatology near tree line in Hawaii. Agricultural and Forest Meteorology, 66, 159-172.

Karr, J.R. \& Freemark, K.E. (1983) Habitat selection and environmental gradients: dynamics in the 'stable' tropics. Ecology, 64, 1481-1494.

Krushelnycky, P.D. \& Reimer, N.J. (1996) Efforts at control of Argentine ants in Haleakala National Park, Maui, Hawaii, Technical Report, Vol. 109, pp. 1-33. Cooperative National Park Resources Studies Unit, HI, USA.

Lamoureux, C.H., Mueller-Dombois, D. \& Bridges, K.W. (1981) Temporal variation of organism groups studied: trees. Island ecosystems: biology organization in selected Hawaiian communities (eds D. Mueller-Dombois, K.W. Bridges and H.L. Carson), pp. 391-407. Hutchinson Ross Publishing Co, Stroudsburg, PA and Woods Hole, MA, USA.

Ley, R.E. \& D’Antonio, C.M. (1998) Exotic grass invasion alters potential rates of $\mathrm{N}$ fixation in Hawaiian woodlands. Oecologia, 113, 179-187.

Loiselle, B.A. \& Blake, J.G. (1991) Temporal variation in birds and fruits along an elevational gradient in Costa Rica. Ecology, 72, 180-193.

MacDonald, J.F., Akre, R.D. \& Hill, W.B. (1973) Attraction of yellowjackets (Vespula spp.) to heptyl buterate in Washington State (Hymenoptera: Vespidae). Environmental Entomology, 2, 375-379.

Martin, T.E. (2001) Abiotic vs. biotic influences on habitat selection of coexisting species: climate change impacts? Ecology, 82, 175-188.

Mueller-Dombois, D. (1973) A non-adapted vegetation interferes with water removal in a tropical rain forest area in Hawaii. Tropical Ecology, 14, 1-16.

Mueller-Dombois, D. (1981) Spatial integration of the organisms studied along the transect. Island ecosystems: biological organization in selected Hawaiian communities (eds D. Mueller-Dombois, K.W. Bridges and H.L. Carson), pp. 181-210. Hutchinson Ross Publishing Co, Stroudsburg, PA and Woods Hole, MA, USA.

Olson, S.L. \& James, H.F. (1991) Descriptions of thirty-two new species of birds from the Hawaiian Islands. Part I. NonPasseriformes. Ornithological Monographs, 45, 1-88.

Perkins, R.C.L. (1903) Vertebrata. Fauna Hawaiiensis, Vol. 1, pt 4 (ed. D. Sharpe), pp. 365-466. University Press, Cambridge, UK.

Pletschet, S.M. \& Kelly, J.F. (1990) Breeding biology and nesting success of palila. Condor, 92, 1012-1021.

Poulin, B., Lefebvre, G. \& McNeil, R. (1992) Tropical avian phenology in relation to abundance and exploitation of food resources. Ecology, 73, 2295-2309.
Pratt, T.K., Banko, P.C., Fancy, S.G., Lindsey, G.D. \& Jacobi, J.D. (1997) Status and management of the Palila, an endangered honeycreeper, 1987-1996. Pacific Conservation, 3, 330-340.

Rahbek, C. (1995) The elevational gradient of species richness: a uniform pattern? Ecography, 18, 200-205.

Rahbek, C. (1997) The relationship among area, elevation, and regional species richness in neotropical birds. American Naturalist, 149, 875-902.

Ralph, C.J. \& Fancy, S.G. (1994) Timing of breeding and molting in six species of Hawaiian honeycreepers. Condor, 96, 151-161.

Ralph, C.J. \& Fancy, S.G. (1995) Demography and movements of apapane and iiwi on Hawaii. Condor, 97, 729-742.

Remsen, J.V. Jr, \& Graves, W.S. IV. (1995) Distribution patterns and zoogeography of Atlapetes brush-finches (Emberizinae) of the Andes. Auk, 112, 210-224.

Repasky, R.R. \& Schluter, D. (1994) Habitat distributions of wintering sparrows along an elevational gradient: tests of the food, predation and microhabitat structure hypotheses. Journal of Animal Ecology, 63, 569-582.

van Riper,C. III (1980a) The phenology of the dryland forest of Mauna Kea, Hawaii, and the impact of recent environmental perturbations. Biotropica, 12, 282-291.

van Riper,C. III (1980b) Observations on the breeding of the palila Psittirostra bailleui of Hawaii. Ibis, 122, 462-475.

van Riper,C. III (1984) The influence of nectar resources on nesting success and movement patterns of the Hawaii amakihi (Hemignathus virens). Auk, 101, 38-46.

van Riper,C. III, Scott, J.M. \& Woodside, D.M. (1978) Distribution and abundance patterns of the palila on Mauna Kea, Hawaii. Auk, 95, 518-527.

van Riper,C., III, van Riper, S.G., Goff, M.L. \& Laird, M. (1986) The epizootiology and ecological significance of malaria in Hawaiian land birds. Ecological Monographs, 56, 327-344.

Sabo, S.R. (1980) Niche and habitat relations in subalpine bird communities of the White Mountains of New Hampshire. Ecological Monographs, 50, 241-259.

Scott, J.M., Mountainspring, S., Ramsey, F.L. \& Kepler, C.B. (1986) Forest bird communities of the Hawaiian Islands: their dynamics, ecology, and conservation. Studies in Avian Bio$\log y$, 9, 1-431.

Scott, J.M., Mountainspring, S., van Riper, C. III, Kepler, C.B., Jacobi, J.D., Burr, T.A. \& Giffin, J.G. (1984) Annual variation in the distribution, abundance, and habitat response of the palila (Loxioides bailleui). Auk, 101, 647-664.

Scowcroft, P.G. \& Conrad, C.E. (1992) Alien and native plant response to release from feral sheep browsing on Mauna Kea. Alien plant invasions in native ecosystems in Hawai' $i$ : management and research (eds C.P. Stone, C.W. Smith and J.T. Tunison), pp. 625-665. Cooperative National Park Resources Studies Unit, University of Hawai'i, Honolulu, HI, USA.

Scowcroft, P.G. \& Giffin, J.G. (1983) Feral herbivores suppress Sophora and other browse species on Mauna Kea, Hawaii. Journal of Range Management, 36, 638-645.

Smith, C.W. \& Tunison, J.T. (1992) Fire and alien plants in Hawaii: research and management implications for native ecosystems. Alien plant invasions in native ecosystems of 
Hawai' $i$ : management and research (eds C.P. Stone, C.W. Smith and J.T. Tunison), pp. 394-408. Cooperative National Park Resources Studies Unit, University of Hawai'i, Honolulu, HI, USA.

Sokal, R.R. \& Rohlf, F.J. (1981) Biometry, 2nd edn, p. 859. W.H. Freeman \& Co., New York, NY, USA.

Steadman, D.W. (1995) Prehistoric extinctions of Pacific island birds: biodiversity meets zooarchaeology. Science, 267, 11231131.

Stone, C.P., Cuddihy, L.W. \& Tunison, J.T. (1992) Responses of Hawaiian ecosystems to removal of feral pigs and goats. Alien plant invasions in native ecosystems of Hawai $i$ : management and research (eds C.P. Stone, C.W. Smith and J.T. Tunison), pp. 666-704. Cooperative National Park Resources Studies Unit, University of Hawaici, Honolulu, HI, USA.

Terborgh, J. (1977) Bird species diversity on an Andean elevational gradient. Ecology, 58, 1007-1019.

Tomich, P.Q. (1981) Altitudinal distribution of organisms along an island mountain transect: rodents. Island ecosystems: biological organization in selected Hawaiian communities (eds D. Mueller-Dombois, K.W. Bridges and H.L. Carson), pp. 105-110. Hutchinson Ross Publishing Co., Stroudsburg, PA and Woods Hole, MA, USA.

Warner, R.E. (1968) The role of introduced diseases in the extinction of the endemic Hawaiian avifauna. Condor, 70, 101-120.

Wetterer, J.K., Banko, P.C., Laniawe, L.P., Slotterback, J.W. \& Brenner, G.J. (1998) Nonindigenous ants at high elevations on Mauna Kea, Hawai'i. Pacific Science, 52, 228-236.

Wheelwright, N.T. (1983) Fruits and the ecology of resplendent quetzals. Auk, 100, 286-301.

Williams, A.C. (1994) Effects of non-native grasses on a dry subalpine forest native to Hawaii and a discussion of effects of canopy on understory productivity. MSc Thesis, University of California, Berkeley, CA, USA.

Young, B.E., DeRosier, D. \& Powell, G.V.N. (1998) Diversity and conservation of understory birds in the Tilarán Mountains, Costa Rica. Auk, 115, 998-1016.

\section{BIOSKETCHES}

Paul Banko (PhD) has been investigating the ecology and conservation of palila (Loxioides bailleui) since 1988 and leads the Palila Restoration Project. His research interests are in the ecology and conservation of Hawaiian birds with emphasis on population and habitat restoration, food ecology, and impacts of invasive species. Studies of insect ecology and diet composition (Peter Oboyski and John Slotterback), vegetation composition and structure and tree phenology (Steven Dougill and Megan Laut), predator impacts and behaviour (Dan Goltz), and avian ecology and restoration (Luanne Johnson and Colleen Murray) continue on Mauna Kea, although some project biologists have moved on to pursue other research interests and opportunities. Pete is now enrolled in a $\mathrm{PhD}$ programme in entomology at the University of California, Berkeley, and will examine the ecology and systematics of Hawaiian Cydia moths. Luanne is pursuing a PhD in environmental studies at Antioch New England Graduate School, New Hampshire, and Megan is working with the Hawai'i Natural Heritage Program centered at the University of Hawai'i at Mānoa. 